\title{
Patterns of Quaternary uplift of the Corinth rift southern border ( $N$ Peloponnese, Greece) revealed by fluvial landscape morphometry
}

\author{
A. Demoulin ${ }^{\text {a,b }}$, A. Beckers ${ }^{\text {a,c }}$, A. Hubert-Ferrari ${ }^{\text {a }}$ \\ ${ }^{a}$ Dept. of Physical Geography and Quaternary, University of Liège, Liège, Belgium \\ ${ }^{b}$ Fund for Scientific Research - FNRS, Brussels, Belgium \\ ${ }^{c}$ Fund for Scientific Research — FRIA, Brussels, Belgium
}

\begin{abstract}
The Rift of Corinth is a world-class example of young active rifting and, as such, is an ideal natural laboratory of continental extension. However, though much investigated for two decades, several aspects of the mechanisms at work are still poorly understood. The aim of this paper is a detailed morphometric study of the fluvial landscape response to the tectonic uplift of the rift southern shoulder in order to reconstruct the rift's Quaternary evolution, with special attention to timing, location, and intensity of uplift episodes. Based on the use of a large set of catchment and long profile metrics complemented by the new $R / S_{\mathrm{R}}$ integrative approach of the regional drainage network, we identified three distinct episodes of uplift of the northern Peloponnese coastal tract, of which the intermediate one, dated around 0.35-0.4 Ma, is only recorded in the topography of the central part of the rift shoulder, and the youngest one appears to have propagated from east to west over the last 10-20 ka. While net uplift remained minimum in the eastern part of the study area during the whole Quaternary, it shows a clear maximum in the central part of the rift shoulder since $0.4 \mathrm{Ma}$ and an eastward shift of this maximum in recent times. Maximum uplift rates calculated from the morphometric data are of > 1.05 and 2-5 mm year ${ }^{-1}$ for, the mid-Middle Pleistocene and Holocene uplift episodes, respectively. The morphometric evidence reveals an onshore uplift history remarkably consistent with the rift evolution reconstructed from other data sets. In the long term, it shows a stable pattern of maximum activity in the central part of the rift, confirming previous conclusions about the absence of rift propagation. In the short term, it sheds light on a possible E-W migration of the zone of recent uplift, suggesting that in the near future fault activity and seismic hazard might concentrate in the Heliki-Aegion area, at the western tip of this uplift wave.
\end{abstract}

KEYWORDS: Aegean domain Corinth rift Geomorphometry Uplift

\section{INTRODUCTION}

The Rift of Corinth is the most active extensional crustal structure currently observable in Europe and, as such, it has been used for more than 20 years as a natural laboratory where multiple studies are conducted to understand the mechanisms at work at various scales from regional geodynamic through rift to individual fault scales. Despite all efforts, the debate goes on about several important issues, among which is a need for a more detailed knowledge of the Plio-Quaternary evolution of the basin and its emerged margins, especially regarding chronology (e.g., Ford et al., 2013), E-W variations in subsidence and uplift along its southern border (e.g., McNeill and Collier, 2004; Bell et al., 2009), and the discrepancy between moderate Pleistocene and high modern extension rates (e.g., Bell et al., 2011).

In this study, we carry out an in-depth morphometric analysis of the 10 largest catchments draining the Peloponnesian margin of the rift of Corinth in order to unravel and date the uplift history of the area. We apply a comprehensive set of morphometric tools (catchment, drainage network, and river long profile metrics and indices) for identifying the landscape response to spatially and temporally variable uplift signals. We find that the fluvial landscape keeps a detailed record of the last three uplift episodes that affected the northern Peloponnese. Our results support recent findings both onshore and offshore, and provide an independent and broader insight in the timing and the spatial variations of uplift along the rift shoulder. This should help in investigating the factors and mechanisms responsible for the Quaternary S-N migration of the rift.

\section{GEOLOGICAL AND GEOMORPHOLOGICAL SETTING}

The Rift of Corinth is the main extensional structure currently active in the back-arc region of the Hellenic subduction zone (Fig. 1) and, as such, is one of the most seismically hazardous areas of the Mediterranean region, with frequent $M_{\mathrm{w}}>6$ earthquakes. Crustal thinning is especially marked in its eastern part, with crustal thickness in the order of $28-30 \mathrm{~km}$, while the thickened crust $(>40 \mathrm{~km})$ of the Hellenides is hardly affected in its western part (Sachpazi et al., 2007). The rift is $\sim 105 \mathrm{~km}$ in length and, with its WNW-ESE strike, cuts obliquely 
through the NNW-trending Mesozoic-Paleogene nappe stack of the Hellenides (Fig. 1), mainly made of Mesozoic carbonates, plus some Paleocene flyschs (Doutsos et al., 2006). One of several transverse faults that segmented the Mesozoic Pindos Ocean, the Corinth Gulf Fault Zone, contributed toward deviating the structural grain of the hinterland Parnassos zone in a WNW-ESE direction, just to the north of the present gulf (Skourlis and Doutsos, 2003). Beyond being situated approximately at the tip of the SW-propagating North Anatolian Fault (Armijo et al., 1999) (Fig. 1), the exact location of the Plio-Quaternary Rift of Corinth might thus have been determined also by these inherited features (Taylor et al., 2011).

Fig. 1. Tectonic setting of the study area. Ps: Psathopyrgos fault Se: Selinitika fault. Ae: Aegion fault La: Lakka fault WH: West Heliki fault EH: East Heliki fault. Kr: Krathis fault De: Derveni faut Si: Sithas fault. Xy: Xylokastro fault P-M: Pirgaki-Mamousia fault. Va: Valimi fault Kia: Kiato fault Do: Doumena fault. Ke: Kerpini fault Ka: Kalavrita fault. Kil: Kilini fault. N/SE: North and South Eratini faults. WC: West Channel fault. EC: East Channel fault Shaded areas represent Plio-Quaternary deposits. Oblique hatching represents zones of marine terrace preservation. Inset. HS: Hellenic subduction zone. NAF: North Anatolian Fault

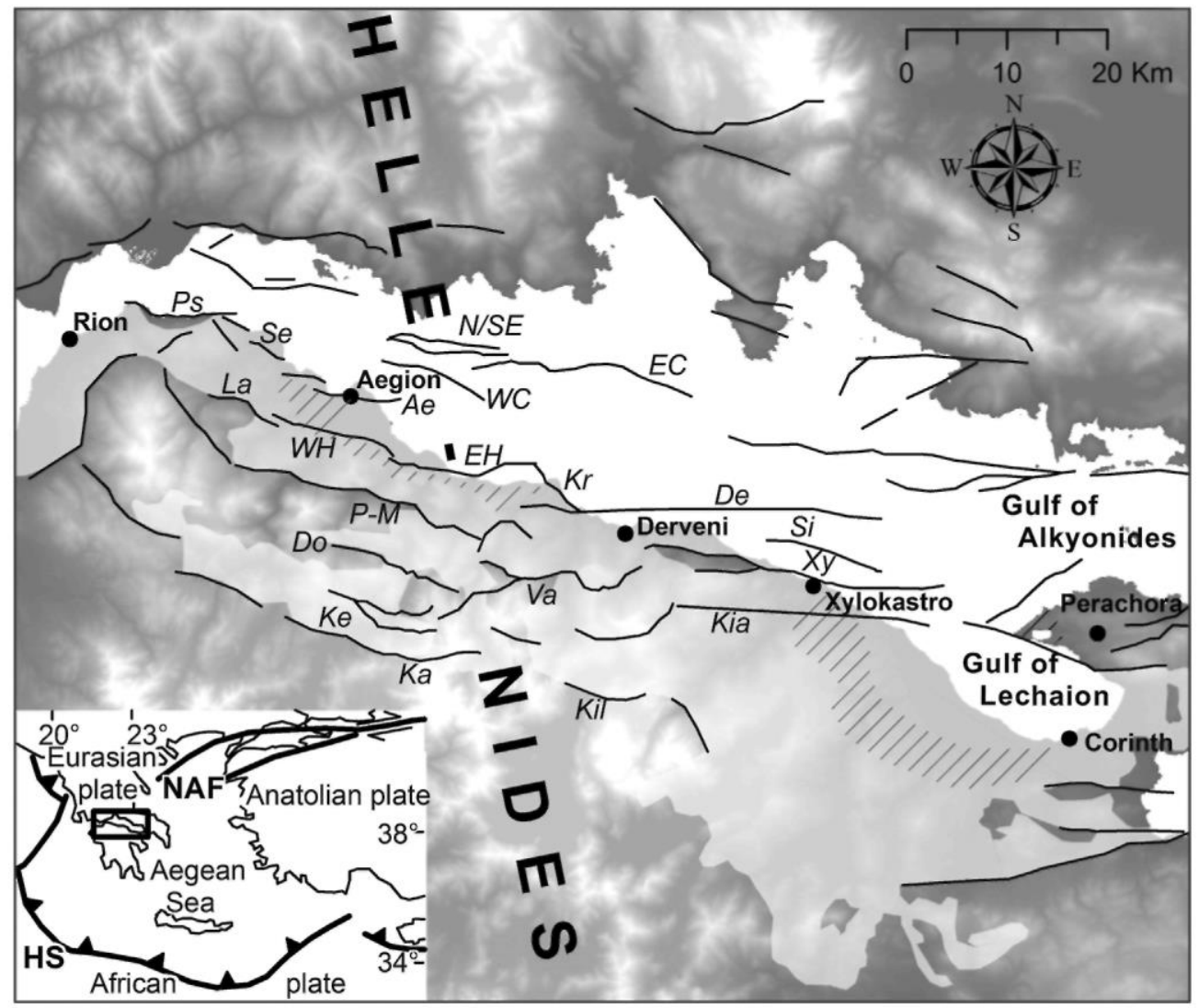

The Corinth gulf is widest $(25-30 \mathrm{~km}$ ) in its east-central part, where it is also deepest (with a maximum water depth of $900 \mathrm{~m}$ ) and records the thickest syn-rift sediment pile (up to $\sim 3000 \mathrm{~m}$ - Taylor et al., 2011). While it prolongs eastward into two branches formed by the much shallower ( 200-m-deep) Alkyonides and Lechaion gulfs, it rapidly narrows to $10 \mathrm{~km}$ and less west of Heliki and Aegion. Although the basin's deep prolongs to the west in a longitudinal canyon that dissects the gulfs bottom, water depth diminishes to less than $400 \mathrm{~m}$, down to a $\sim 60 \mathrm{~m}$ sill depth where the Rion-Antirion strait connects the Corinth and Patras gulfs.

The faulted margins of the rift are comprised of roughly E-W normal faults. Many seismic reflection studies contributed in the last decade toward an improved mapping of active offshore faults (e.g., Stefatos et al., 2002; Lykousis et al., 2007; Bell et al., 2008; Taylor et al., 2011; Beckers et al., 2015). The mostly north-dipping faults of the southern margin are grouped in several parallel lines of right-stepping en-échelon faults, both on- and offshore. The presence of uplifted syn-rift sediments widely exposed in the northern Peloponnese bears witness to a significant uplift of the southern rift shoulder (Rohais et al., 2007a; Ford et al., 2013). By contrast, most faults of the northern margin are located in a narrow zone situated within the drowned part of the rift. In agreement with the more winding northern coastline, the widening of the gulf into the Itea and Antikyra bays, and the absence of exposed sediments on that side of the basin, this indicates that the northern rift shoulder undergoes subsidence (Stefatos et al., 2002; Bell et al., 2009). 
The starting time of the Corinth rift formation is still not well constrained. While Doutsos and Piper (1990) make the oldest rift fill Middle to Late Pliocene in age, Rohais et al. (2007b) and Ford et al. (2013) put the initial stages of rifting in a time period encompassing the Upper Pliocene and the Lower Pleistocene and date the first rift deepening event from between 1.8 and 1.5 Ma. Recently, Leeder et al. (2012) dated their so-called "Great Deepening event" from 3.2 to $3 \mathrm{Ma}$ in the east-central rift sector. In their evolution scheme, it corresponds to focused extension on the Killini and Mavro faults and might therefore tentatively be correlated with the initial rifting stage of Rohais et al. (2007b), although the latter authors envisage this phase as one of slow extension and subsidence. Based notably on detailed studies of the syn-rift fill exposed on the uplifted southern shoulder of the west-central rift (e.g., Ori, 1989; Rohais et al., 2007b; Ford et al., 2013), and though its chronology is still debated, the following multiphase rift evolution is now commonly accepted. The initial rifting stages caused fluvio-lacustrine sediments to accumulate within a fairly large area where all faults more or less participated in accommodating slow subsidence (extension rates $<1 \mathrm{~mm}$ year $^{-1}$; Ford et al., 2013). To the south, this area extended as far as the Kalavrita and Killini faults (Fig. 1). These continental environments then progressively gave way to brackish environments interrupted by brief marine incursions, leading to a second evolution stage that would have started around 1.5 Ma (Rohais et al., 2007b; Leeder et al., 2012). This second stage was marked by an abrupt increase in extension (2-2.5 $\mathrm{mm} \mathrm{year}^{-1}$ ) and subsidence rates (individual fault slip rates in the order of 1-2 $\left.\mathrm{mm} \mathrm{year}^{-1}\right)$. Antecedent rivers incising the elevated hinterland started to accumulate, mainly north of a line joining the Pirgaki, Mamousia, and Kilini faults, huge alluvial fans going northward into giant Gilbert-type deltas. During their estimated -0.8 Ma lifetime, northward progradation of the deltas, possibly recording the northward migration of the uplifting area (Rohais et al., 2007a), progressively shifted the central gulfs southern shoreline by about $15 \mathrm{~km}$ (Rohais et al., 2007b). By contrast, in the west, Ford et al. (2013) suggest that northward migration of fault activity onto the Pirgaki and Mamousia faults occurred more abruptly at the beginning of this stage. A third phase of the rift evolution is estimated to have begun sometime around or after $0.7 \mathrm{Ma}$ and was again characterized by accelerated extension, reaching rates in the order of 3.4-4.8 $\mathrm{mm} \mathrm{year}^{-1}$ (Ford et al., 2013) and by a further $5 \mathrm{~km}$ northward migration of the southern rift margin, which came to coincide with the Heliki (and onshore Xylokastro?) faults. Consequently, the first-generation Gilbert fan deltas were incised by the drainage network establishing on the uplifting footwall of these faults, thus delivering material to new deltas prograding on their hangingwall. These deltas are, for the greatest part, still developing at present, with their front making the steep underwater slopes of the southern border of the basin. Onshore, the presence of Middle Pleistocene marine terraces south of the Heliki and Xylokastro faults (Keraudren et al., 1995; Armijo et al., 1996; McNeill and Collier, 2004; De Martini et al., 2004; McNeill et al., 2005) attest the ongoing footwall uplift of Middle Pleistocene faults.

Finally, observations of uplifted Holocene corrosion notches, lithophaga perforations and corals at the seaside just south of the Heliki and Xylokastro faults (Pirazzoli et al., 2004) and the recent partial transfer of activity from the Heliki to the northward located Aegion fault might be interpreted as precursors of a further migration of fault activity across the southern rift margin. In any case, this recent evolution coincides with an apparent increase in modern extension rates. Indeed, GPS measurements in the Corinth gulf area indicate current rates ranging from $<5 \mathrm{~mm}_{\text {year }}{ }^{-1}$ at the eastern end of the rift to $11 \mathrm{~mm} \mathrm{year}^{-1}$ at the height of Xylokastro and $16 \mathrm{~mm}$ year $^{-1}$ in the western rift (Avallone et al., 2004; Nyst and Thatcher, 2004; Bernard etal., 2006). However, beyond the fact that the E-W variation of these rates does not superpose with long-term variations showing maximum total extension in the central rift (Bell et al., 2011), the question of how, if ever, geologically instantaneous GPS rates may compare with long-term averaged rates is still debated (e.g., Friedrich et al., 2003; Bell et al., 2011).

On the northern side of the basin, Bell et al. (2008) observe partial northward transfer of fault activity from the West and East Channel faults to the South and North Eratini faults (Fig. 1) since 0.5 Ma. Though consistent with evidence of subsidence of the northern rift margin, such migrating fault activity is limited to this small westcentral part of the graben and, even there, did not exceed $\sim 8 \mathrm{~km}$, a much lower figure than in the south. It thus just tempers locally the progressive focusing of the deformation and the rift narrowing that accompanied the latter's northward migration (Bell et al., 2009; Taylor et al., 2011).

Offshore, the identification of major seismic reflectors widely distributed throughout the basin leads to distinguish successive sequences within the basin fill (e.g., Bell et al., 2011; Taylor et al., 2011). However, in the absence of drill-hole data, a major obstacle in using such sequence boundaries is the difficulty to establish a reliable chronostratigraphy. The approach adopted by most authors in the Rift of Corinth has thus been to refer alternating packages of high-amplitude and low-amplitude reflectors to either lacustrine or marine sedimentation and to correlate the identified marine-lacustrine interfaces with the times when the glacio-eustatic sea-level curve passed across the eustatic level corresponding to the depth of the Rion-Antirion sill. Although contradictory models have been used in linking reflector packages to specific environments (Piper and Perissoratis, 1991; Leeder et al., 1998; Perissoratis et al., 2000; Collier et al., 2000), the recent study of Taylor et al. (2011) provides 
a synthesis of the seismic imaging information across the Rift of Corinth at the $10^{5}$ year time scale. They distinguish two first-order packages of reflectors in the basin fill, which they refer to an early-rift and a late-rift section, putting the transition around 0.68 Ma. Moreover, they recognize two second order boundaries within the latter section, which they date back to 0.335 and 0.130 Ma. However, Nixon et al. (2013) consensually displace the main transition from $\sim 0.68$ to $0.60 \mathrm{Ma}$ because the late-rift section is made of six marine-lacustrine packages that they associate to the last six glacial cycles. This $0.6 \mathrm{Ma}$ discontinuity corresponds also to the main boundary within the seismic profiles that Bell et al. (2008, 2009) put around 0.4 Ma. Keeping in mind the dating uncertainties, the isopach maps of Taylor et al. (2011) describing sedimentation in the gulf show that, before 0.7 Ma, two separate depocentres existed, a main one situated in the west-central gulf in front of the southern coast between Akrata and Derveni, and a minor one in the eastern gulf. Then, from $0.7 \mathrm{Ma}$, they were replaced by a unique larger zone of focused sedimentation located again in the southern half of the basin, between Derveni and Kiato. The locus of maximum deposition within this Middle Pleistocene depocentre seems to have migrated eastward with time, being located in front of Xylokastro on the post-0.130 Ma map. Though less detailed in time, the reconstructions of Bell et al. (2009) also support this spatio-temporal distribution of sedimentation, with two depocentres before 0.4 Ma, from which the one in front of Akrata was the most active, then an elongate depocentre from Derveni to Kiato after 0.4 Ma, with maximum sedimentation in front of Xylokastro.

A major onshore implication of the northward migration of the southern rift margin was the emergence of successive tracts of land in the footwall of the active faults. There, up to 2800-m-thick synrift sediments have been uplifted and, subsequently, exposed to erosion (Rohais et al., 2007a). The resulting geomorphological sequence of the northern Peloponnese displays, from south to north (1) drainage networks strongly incised within former uplifted footwall blocks, with deep narrow gorges (e.g., the Vouraikos gorge) and valley depths of 500 to $800 \mathrm{~m}$; (2) characteristic braided channels in the middle and lower river reaches, transferring huge amounts of sediments delivered by the eroding uplifted deltas; (3) coastal areas extending a few kilometres inland and showing poorly developed drainage systems and limited incision in the uplifting footwall of the currently active rift margin; and (4) development of large fan deltas along the modern shoreline. Owing to the proximity of the crestline of the northern Péloponnèse, distant by less than $50 \mathrm{~km}$ from the coastline, and to footwall backtilting, the river catchments are limited in size. With a length of $49 \mathrm{~km}$ and a catchment area of 366 $\mathrm{km}^{2}$, the Selinous is the largest Peloponnesian river draining to the Corinth gulf. Backtilting also caused drainage reversal toward poljes developed in the limestone basement cropping out in the south (Feneos, Stymfalia), forming endorheic basins at the expense of the north-flowing rivers (Rohais et al., 2007a). Furthermore, karstic phenomena are also present in the catchments of some of these rivers (e.g., the Asopos), significantly reducing discharge and stream power in the concerned reaches.

Footwall uplift associated with the current line of active faults had a further consequence that successive Middle and late Pleistocene shorelines have been raised in marine terraces along the southern gulf coast, offering dating potential and insight into uplift rates. A flight of up to 10 terraces has been described in various places. They are in particular fairly continuously preserved between Corinth and Xylokastro (Keraudren and Sorel, 1987; Collier etal., 1992; Keraudren et al., 1995; Armijo etal., 1996), but also on the footwall of the Aegion and Heliki faults between Aegion and Akrata (De Martini et al., 2004; McNeill and Collier, 2004; McNeill et al., 2005). Stepped marine terraces have also been observed at both the eastern and western ends of the rift, respectively in the Perachora Peninsula (Dia et al., 1997; Morewood and Roberts, 1999; Maroukian et al., 2008) and on the footwall of the Psathopyrgos fault (Houghton et al., 2003) (Fig. 1). However, in many cases, only few and often questionable dating results are available and the terrace chronology mostly relies on linear best fits (often performed visually) between terrace elevation and marine isotope stages associated with high sea level. Based on such sparse anchor points, the terrace flight is generally said to extend over the last 0.3-0.55 Ma and allows inferences about uplift rates in the order of 1-2 mm year ${ }^{-1}$ (Keraudrenetal., 1995; Armijc et al., 1996; De Martini et al., 2004; McNeill and Collier, 2004). Whereas moderate (Houghton et al., 2003: 0.7 mm year ${ }^{-1}$ ) to high (Palyvos et al., 2007, 2010: 1.8 $\mathrm{mm}_{\text {year }}{ }^{-1}$ ) rates have been inferred for the western end of the rift, they rapidly decrease toward the eastern end of the gulf, down to $0.3 \mathrm{~mm}_{\text {year }}{ }^{-1}$ near Corinth (Collier et al., 1992) As for the marine terraces of the Perachora Peninsula, which suggest uplift rates between 0.3 and $0.7 \mathrm{~mm} \mathrm{year}^{-1}$ (Morewood and Roberts 1999), they are indicative of uplift north of the south-dipping Loutraki fault and cannot thus be used to discuss the evolution of the southern rift margin.

The higher uplift rates inferred in the central sector of the northern Péloponnèse coast are also confirmed by Rohais et al. (2007a), whose restoration of the syn-rift infill implies that the Krathis region was most uplifted. Moreover, uplifted Holocene marine deposits and corrosion notches along the coast of the central rift have recorded recently accelerated uplift, with rates up to 3-3.5 mm year ${ }^{-1}$ (Pirazzoli et al. 2004; De Martini et al., 2004). 


\section{METHODS}

Based on the assumption that the 3D shape of fluvial catchment; preserves a detailed record of the regional tectonic history, our analysis of the main Peloponnesian catchments draining into the Gulf of Corinth relies on an extended set of morphometric measurements. The data set refers to 10 catchments (Fig. 2) with size ranging from 65 (Meganitis) to $366 \mathrm{~km}^{2}$ (Selinous) (Table 1). We do not include the Vouraikos catchment because its extreme elongation and the resulting limited development of its tributary network significantly bias several calculated metrics. However, owing to its crucial position in the west-central sector of the rift, the morphological characteristics of the Vouraikos valley, and those of the nearby Ladopotamos valley as well, will be called upon to support the discussion. We first examine information delivered by metrics describing catchment hypsometry. Then, we turn to classical metrics of river long profiles, namely profile concavity and steepness (Flint, 1974; Wobus et al., 2006), determined with the aid of the integral or 'chi plot' approach of Perron and Royden (2013). Finally, we use the $R$ metric and the derived $S_{\mathrm{R}}$ index proposed by Demoulin (2011) to describe the stage reached by the whole landscape in its response to the tectonic signals and estimate the age of the latter.

All metrics were satisfactorily estimated from an ISTAR digital elevation model produced from aerial photographs. Pixel size is $20 \times 20 \mathrm{~m}$, and standard deviation of elevation values is $\sim 10 \mathrm{~m}$. Hydrological correction of the DEM and data extraction were carried out with ArcMap 10.2, with first-order streams of the drainage network defined to start for catchment area $=0.5 \mathrm{~km}^{2}$.

\subsection{Basin hypsometry}

The notions of hypsometric curve and integral were popularized by Strahler (1952). Plotting normalized elevations against normalized areas, the hypsometric curve describes the cumulative distribution of elevations within a catchment. The associated hypsometric integral $\mathrm{H}_{\mathrm{b}}$ corresponds to the surface under the curve (Fig. 3A). It represents the rock volume of the basin as a percentage of a unit volume whose generatrix is the horizontal surface delimited by the basin perimeter and whose base is at basin outlet's elevation and top at basin highest point's elevation. The hypsometric integral is thought to provide a quantitative estimate of basin dissection and thus of the state of landscape evolution, which may be interpreted in terms of response to tectonics (e.g., Chen et al., 2003; Perez-Peña et al., 2009a; Gao et al., 2013) or of prevailing erosion processes, for example glacial versus fluvial erosion (e.g., Brocklehurst and Whipple, 2004; Korup et al., 2005; Sternai et al., 2011). However, while uncertainty about the initial topography biases to some extent the relative meaning of such quantities, similar values of the integral may also correspond to quite different shapes of the hypsometric curve and witness very different stages and/or mechanisms of landscape evolution (Bishop et al., 2002). This underscores the need for additional analysis of the shape of the curve, which is performed only qualitatively in most cases and consequently provides hardly instructive information. Beyond Strahler (1952), who showed that a mathematical function involving three free parameters can be fitted to most natural hypsometric curves (see also Willgoose and Hancock, 1998), a notable exception to this is the use of the hypsokyrtome, a shape parameter Sternai et al. (2011) devised to evaluate the degree of glacial erosion of a landscape on the basis of the hypsometric curve. However, because the hypsokyrtome was of no particular benefit in the northern Peloponnese setting of fluvially dissected tectonic blocks, we built another shape descriptor $\left(\mathrm{H}_{\mathrm{d} / \mathrm{u}}\right)$ corresponding to the ratio between the integrals of respectively the lower (right) and the upper (left) half of the curve (Fig. 3A). $\mathrm{H}_{\mathrm{d} / \mathrm{u}}$ is aimed at quantitatively describing the degree of imbalance between the upper, hardly dissected regions of the catchment and the eroded lower regions, which in turn should be indicative of the stage reached by fluvial incision and lateral erosion. 
Fig. 2. Location map of the 10 studied catchments: 1: Phoenix. 2: Meganitis. 3: Selinous. 4: Kerynitis. 5: Krathis. 6: Krios. 7: Trikalitikos. 8: Asopos. 9: Raizanis. 10: Xerias. Referring to distance in km, the white 0-100 line locates the information provided in Figs. 5, 10 and 11.

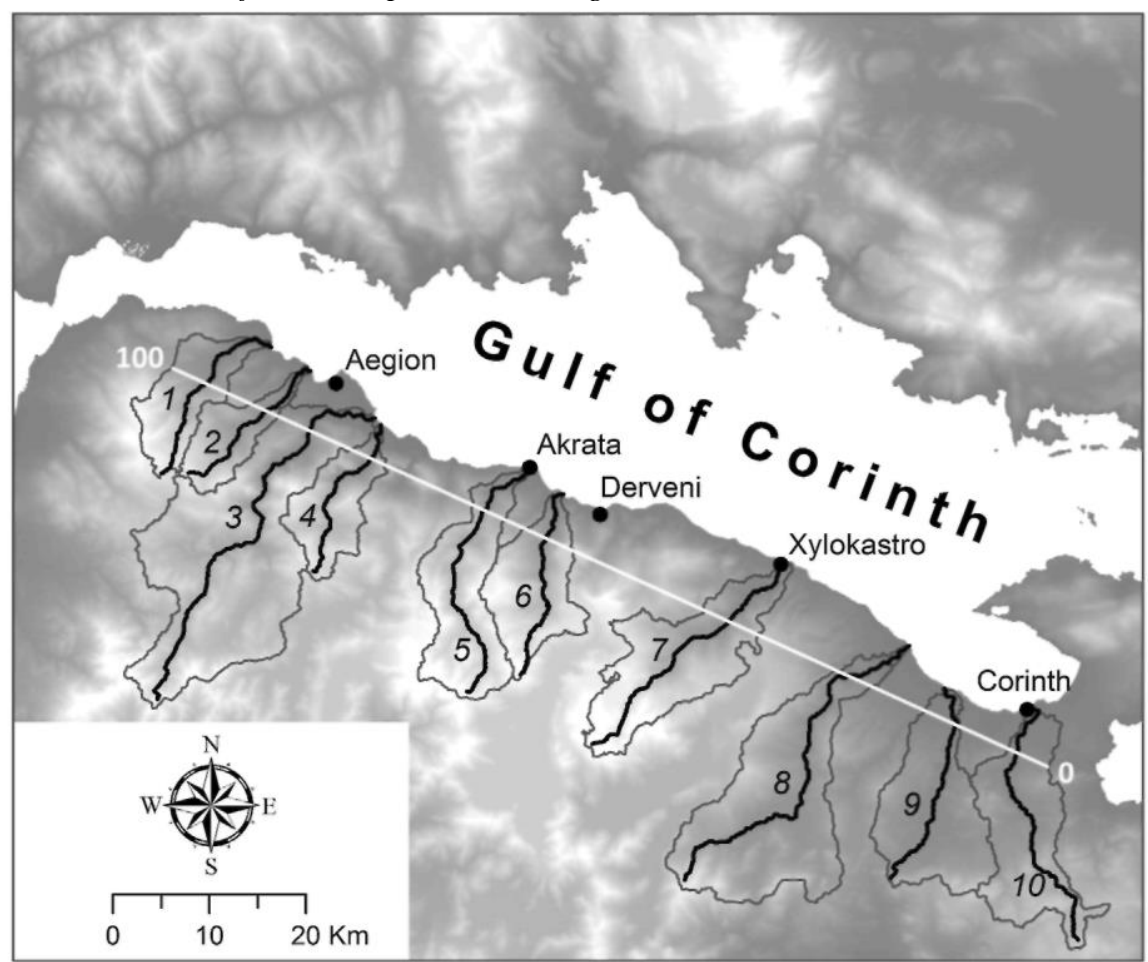

Fig. 3. Hypsometric analysis.

A) Definition of the basin metrics used in this study, based on the example of the Selinous. $H_{\mathrm{ss}}$ : hypsometric curve (normalized cumulative distribution of elevations) of the reconstructed summit surface of the catchment (see text for explanation). $H_{\mathrm{b}}$ : basin hypsometric curve. The dark grey surface below $H_{\mathrm{b}}$, noted $\int H_{\mathrm{b}}$, is the basin hypsometric integral (for the sake of brevity, we simply note the integral $H_{\mathrm{b}}$ in the text). The light grey surface $\left(G R=\int H_{\mathrm{ss}}-\int H_{\mathrm{b}}\right)$ is the geophysical relief. $H_{\mathrm{u}}, H_{\mathrm{d}}$. upstream and downstream half of the basin integral, from which $H_{\mathrm{d} / \mathrm{u}}$, a shape descriptor of the hypsometric curve, is calculated. B) $H_{\mathrm{ss}}$ (network): hypsometric curve of the summit surface pixel population corresponding to the drainage network of the catchment $\mathrm{H}_{n}$ : hypsometric curve of the drainage network The light grey surface $\left(G R_{\text {network }}\right)$ is that part of the geophysical relief restricted to the drainage network a proxy for the average fluvial incision below the reference surface. $G R$ and $G R_{\text {network }}$ are here in their normalized form. Their metric equivalent is obtained by multiplication by the catchment relief value.

A

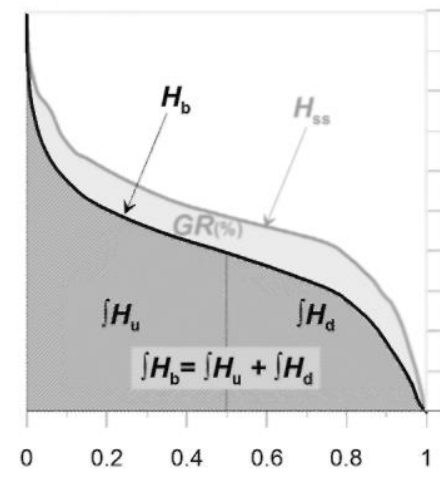

B

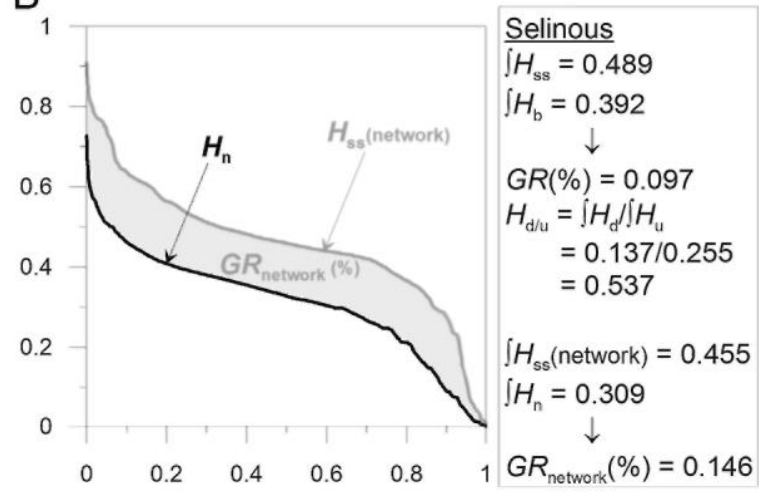


Table 1. General statistics and metrics of the 10 studied catchments.

\begin{tabular}{|c|c|c|c|c|c|c|}
\hline & 1. Phoenix & 2. Meganitis & 3. Selinous & 4. Kerynitis & & 5. Krathis \\
\hline$A\left(\mathrm{~km}^{2}\right)$ & 89.7 & 65.6 & 366.2 & 83.2 & & 144.3 \\
\hline Basin relief $(\mathrm{m})$ & 1933 & 1613 & 2177 & 1775 & & 2351 \\
\hline Bas. elongation & 0.35 & 0.27 & 0.32 & 0.34 & & 0.29 \\
\hline Riv. length (km) & 22.6 & 20.2 & 49 & 20.9 & & 32.3 \\
\hline$H_{\mathrm{b}}$ & 0.405 & 0.436 & 0.392 & 0.490 & & 0.481 \\
\hline$H_{\mathrm{d} / \mathrm{u}}$ & 0.294 & 0.375 & 0.537 & 0.498 & & 0.522 \\
\hline$G R(\mathrm{~m})$ & 121 & 137 & 211 & 260 & & 249 \\
\hline$G R_{\text {network }}(\mathrm{m})$ & 195 & 219 & 318 & 411 & & 414 \\
\hline$H_{\mathrm{d} / \mathrm{u}}$ profile shape & $\mathrm{p} 2 \mathrm{n}^{(1)} \mathrm{i} 2.60^{(2)}$ & $\operatorname{lin} \downarrow$ & p2 $U^{(3)} i 4.01$ & $\mathrm{p} 2 \cap \mathrm{i} 2.30$ & p2 $\cap i 4.09$ & p2 Ui3.35 \\
\hline Riv. segments & b & $\mathrm{a}$ & b & b & & $\mathrm{a}$ \\
\hline
\end{tabular}

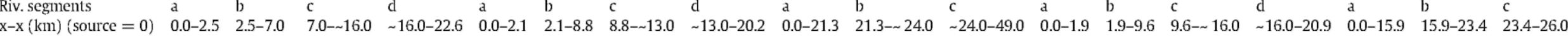

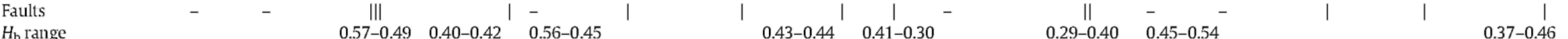

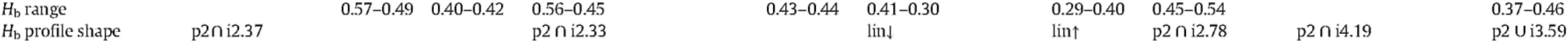
$\begin{array}{llllllll}(\chi) & 0.56 & 1.15 & 0 & 0.49 & 0.51 & 0.55\end{array}$ $\begin{array}{lllllllll} & & \end{array}$ $\begin{array}{lllllll}0 & () & 61- & \mathrm{N} / \mathrm{A} & & 2+ & \mathrm{N} / \mathrm{A}\end{array}$ 0.122

Empty brackets correspond to meaningless values (profile segment too short, insufficient data number) ; ${ }^{(1)}$ profile is convex upward (p2: 2 nd-order polynomial) ; ${ }^{(2)}$ locates the profile inflexion point - value taken from the $\mathrm{x}$ axis $=1 \mathrm{n}(\mathrm{A}) ;{ }^{(3)}$ profile is concave upward; ${ }^{(4)}+$ means that the low end of the upstream chi plot segment is higher than the high end of the downstream segment, - means the opposite; ${ }^{(5)}$ irrelevant

\section{Table 1 (continued)}

\begin{tabular}{|c|c|c|c|c|c|c|c|c|c|c|c|c|c|c|c|c|c|c|}
\hline & 5. Krathis & \multicolumn{4}{|l|}{ 6. Krios } & \multicolumn{4}{|c|}{ 7. Trikalitikos } & \multicolumn{4}{|c|}{ 8. Asopos } & \multicolumn{3}{|c|}{ 9. Raizanis } & \multicolumn{2}{|l|}{ 10. Xerias } \\
\hline $\mathrm{A}\left(\mathrm{km}^{2}\right)$ & 144.3 & \multirow{2}{*}{\multicolumn{4}{|c|}{112.8}} & \multicolumn{4}{|l|}{175.9} & \multicolumn{4}{|l|}{276.4} & \multicolumn{3}{|l|}{165.6} & \multicolumn{2}{|l|}{164.4} \\
\hline Basin relief (m) & 2351 & & & & & \multicolumn{4}{|l|}{2374} & \multicolumn{4}{|l|}{1622} & \multicolumn{3}{|l|}{1071} & \multicolumn{2}{|l|}{1130} \\
\hline Bas. elongation & 0.29 & \multicolumn{4}{|l|}{$\begin{array}{l}1881 \\
0.36\end{array}$} & \multicolumn{4}{|l|}{0.28} & \multicolumn{4}{|l|}{0.29} & \multicolumn{3}{|l|}{0.45} & \multicolumn{2}{|l|}{0.32} \\
\hline Riv. length (km) & 32.3 & \multicolumn{4}{|l|}{23.9} & \multicolumn{4}{|l|}{32.3} & \multirow{2}{*}{\multicolumn{4}{|c|}{$\begin{array}{l}44.3 \\
0.315\end{array}$}} & \multicolumn{3}{|l|}{26.1} & \multicolumn{2}{|l|}{33.3} \\
\hline$H_{\mathrm{b}}$ & 0.481 & \multicolumn{4}{|l|}{0.548} & \multirow{2}{*}{\multicolumn{4}{|c|}{$\begin{array}{l}0.405 \\
0.364\end{array}$}} & \multirow{2}{*}{\multicolumn{4}{|c|}{0.315}} & \multicolumn{3}{|l|}{0.264} & \multicolumn{2}{|l|}{0.376} \\
\hline$H_{\mathrm{d} / \mathrm{u}}$ & 0.522 & \multicolumn{4}{|l|}{0.481} & & & & & & & & & 0.375 & & & 0.310 & \\
\hline$G R(\mathrm{~m})$ & 249 & 192 & & & & 159 & & & & 131 & & & & 79 & & & 80 & \\
\hline$G R_{\text {network }}(\mathrm{m})$ & 414 & 301 & & & & 249 & & & & 183 & & & & 94 & & & 115 & \\
\hline$H_{\mathrm{d} / \mathrm{u}}$ profile shape & p2 U i3.35 & p2 $\cap$ i3.6 & & & & $\mathrm{p} 2 \cap \mathrm{i} 3$. & & & & $\mathrm{p} 2 \cap \mathrm{i} 3.4$ & & & $\operatorname{lin} \uparrow$ & p2 $\cup$ i2..5 & $1(?)$ & & $\mathrm{p} 2 \cap \mathrm{i} 3.45$ & \\
\hline Riv. segments & d & a & b & c & d & $\mathrm{a}$ & b & c & $\mathrm{d}$ & a & b & c & $\mathrm{d}$ & $\mathrm{a}$ & b & c & a & b \\
\hline $\mathrm{x}-\mathrm{x}(\mathrm{km})($ source $=0)$ & $26.0-32.3$ & $0.0-2.1$ & $2.1-11.8$ & $11.8-\sim 18.0$ & $\sim 18.0-23.9$ & $0.0-1.2$ & $1.2-7.5$ & $7.5-22.0$ & $22.0-32.6$ & $0.0-1.2$ & $1.2-6.0$ & $6.0-23.2$ & $23.2-44.3$ & $0.0-1.3$ & $1.3-12.0$ & $12.0-26.1$ & $0.0-10.3$ & $10.3-33.3$ \\
\hline Faults & I & - & I & ॥ & 1 & - & - & - & & - & - & - & - & - & - & - & & - \\
\hline$H_{\mathrm{b}}$ range & $0.46-0.48$ & $0.52-0.5$ & & & $0.54-0.55$ & $0.44-0$. & & & $0.44-0.40$ & $0.35-0.2$ & & & $0.22-0.32$ & $0.29-0.2$ & & $0.24-0.27$ & $0.36-0.52$ & \\
\hline$H_{\mathrm{b}}$ profile shape & p2 U 33.59 & - & & & & $\mathrm{p} 2 \mathrm{n}$ i3 & & & & $\mathrm{p} 2 \cap \mathrm{i} 3.0$ & & & $\operatorname{lin} \uparrow$ & p2 Ui 3. & & & p2 $\cap$ i3.85 & \\
\hline$\theta(x)$ & 0.52 & () & 0.48 & 0.38 & & () & 1.29 & 0.90 & & () & 1.11 & 0.77 & 0.48 & () & 0.24 & & 0.57 & 0.85 \\
\hline$k_{\mathrm{sn}}\left(\theta_{\mathrm{ref}}(\chi)=0.5\right)$ & 0.53 & 0 & 0.27 & 0.39 & & 0 & 0.25 & 0.41 & & () & 0.25 & 0.06 & 0.18 & () & 0.07 & & 0.09 & 0.15 \\
\hline$\Delta z$ z segments & $\mathrm{N} / \mathrm{A}$ & () & $113+$ & $\mathrm{N} / \mathrm{A}$ & & 0 & $47-$ & $\mathrm{N} / \mathrm{A}$ & & & $96+$ & $8-$ & $\mathrm{N} / \mathrm{A}$ & 0 & $\mathrm{~N} / \mathrm{A}$ & & $69+$ & $\mathrm{N} / \mathrm{A}$ \\
\hline$S_{\mathrm{R}}$ long profile & 7.658 & 0.429 & & & 9.038 & 0.286 & & & 6.680 & 0.184 & & & 3.425 & 0.172 & & 2.812 & $?$ & \\
\hline
\end{tabular}




\subsection{Geophysical relief}

Small and Anderson (1998) define geophysical relief $G R$ as the mean difference in elevation between a surface connecting the highest points of the present landscape and the latter's true topography. As the higher surface, which we call here 'summit surface', is assumed to represent the topography prior to valley development, $G R$ provides an estimation of the part of the erosion beyond that having lowered the summit points or, in other words, of the nonsteady-state part of erosion caused by valley deepening since the time of the reconstructed summit surface. Though dependent on the quality of the latter, GR is therefore in most cases a better and more flexible estimator of erosion than $H_{\mathrm{b}}$. Small and Anderson (1998) also emphasize that, if summit erosion is very low, $G R$ provides a good estimate of mean erosion.

However, Champagnac et al. (2007) stress that $G R$ strongly depends on the way the summit surface is constructed. In their study of the western Alps, they produce a number of such surfaces by moving a circular window across the study area and recording for each pixel the maximum elevation encountered in the window centred on it. The smaller the window's radius is, the more lower-lying points are included in the summit surface, resulting in a lower mean surface elevation and, consequently, a lower $G R$ value. The appropriate radius must be determined with respect to the scale of the process under investigation.

Here, we use a method very similar to that of Champagnac et al. (2007) to construct the summit surface. Sliding a square window across the study area, we record the in-window maximum elevation for each pixel. Then, we subtract the current topography from the obtained surface and keep only those points for which the result is zero. This set of points is finally used to construct the summit surface by TIN interpolation. We selected a relatively small sliding window size of 500 x $500 \mathrm{~m}$ in order to produce a rather high-resolution summit surface including most second-order ridge summits on top of the Plio-Quaternary delta deposits. Such a summit surface captures a certain degree of the landscape sculpture, which is assumed to reflect fairly well the shape of the areas that were submitted to erosion when faulted blocks successively emerged from the sea since the Pliocene. This was desirable for two main reasons: (1) it prevents $G R$ values from being overestimated because of large vertical offsets between differently uplifted blocks close to each other, and (2) it allows $G R$ estimates to be focused on the middle-term $(<1.5 \mathrm{Ma})$, which is the time scale of interest in this study. As the summit surface too may be described by a hypsometric integral (Fig. 3A), GR is most easily derived from a difference of integrals. It is expressed either in normalized form or in metres, as the corresponding fraction of the basin's relief.

Finally, it may also be useful to think of $G R$ in a narrower sense, restricting its calculation to the DEM's pixels representing the drainage network (Fig. 3B). Subtracting actual valley bottom elevations from the corresponding summit surface elevations yields then a quantitative figure of average river incision, a close proxy for incision in the main branches of the network and, thus, for amplitude of the triggering uplift signal at the time scale associated with the reconstructed summit surface.

\subsection{River profiles: chi plots}

In general, one of two main approaches is used to analyse river long profiles: the stream length-gradient $(S L)$ index of Hack (1973), sometimes normalized in its SLk form (Seeber and Gornitz, 1983; Perez-Peña et al., $2009 \mathrm{~b}$ ), or channel slope-drainage area (S/A) log-log plots allowing the calculation of profile concavity and steepness (Flint, 1974). We privileged the latter approach mainly because (1) the $S L$ index of a river reach is related to profile concavity through fitting a logarithmic function to the river profile, which is in many cases less good than the power law fit assumed in $S / A$ plots; (2) $S L k$ calculations involve the subjective choice of a reference segment length; and (3) more fundamentally, $S L$ data essentially locate anomalies in channel gradient but do not say much about the profile as a whole.

The concavity $\theta$ of a river profile is given by the exponent of the power law relation between channel gradient $S$ and contributing drainage area $A$, while the coefficient of the function corresponds to the profile steepness $k_{s}$ (Flint, 1974)

$S=k_{S} A^{-\theta}$.

Determining profile concavity and steepness from $S$ - $A$ plots implies using noisy elevation data to derive still noisier channel gradient data. Therefore, even after smoothing, vertical scatter and horizontal clustering of the data points (due to abrupt changes in $A$ at confluences) generally weaken the statistical estimation of the parameters, not to speak of the possibility of effectively separating profile segments with different $S$ - $A$ relations. In order to avoid such drawbacks, Perron and Royden (2013) propose a new approach that allows estimation of the profile metrics without passing through slope calculation. They start from the expression for channel gradient at steady state 
with $U=$ uplift rate, $K=$ erosion coefficient, and $\mathrm{n}$ and $\mathrm{m}=$ constants, derived from the generalized stream power equation (e.g., Whipple and Tucker, 2002)

$E=U-K A^{\mathrm{m}} S^{\mathrm{n}}$

with zero net erosion rate $E$. Recalling that $S=d z / d x$, they then simply rewrite Eq. (2) as

$d z=(U / K)^{1 / n} A^{-\mathrm{m} / \mathrm{n}} d x$

and integrate it to obtain, under assumption of constant $U$ and $\mathrm{K}$ values,

$$
z(x)=z\left(x_{0}\right)+\left(\frac{U}{K A_{\mathrm{ref}}^{\mathrm{m}}}\right)^{\frac{1}{2}} \chi
$$

with $x_{0}=$ downstream endpoint of the profile, $A_{\text {ref }}=$ reference drainage area (we putA $\mathrm{A}_{\text {ref }}=1 \mathrm{~km}^{2}$ ), and

$$
\chi=\int_{x_{0}}^{x}\left(\frac{A_{\text {ref }}}{A(x)}\right)^{\frac{m}{2}} d x .
$$

Thanks to the transformation of Eq. (6), Eq. (5) makes elevation of the theoretical profile depends linearly on the new variable $\chi$. Therefore, the concavity of a real river profile, which is represented by the $\mathrm{m} / \mathrm{n}$ exponent of $A$ in Eq. (2), will be given by the $\mathrm{m} / \mathrm{n}$ value in Eq. (6) that yields the best linear fit of the $z=f(\chi)$ profile, called the chi plot. Once concavity has been determined that way, steepness, defined as the coefficient of $A$ in Eq. (2) or, similarly, of $\chi$ in Eq. (5), simply corresponds to the slope of the regression line.

As mentioned above, beyond noise reduction, another advantage of the chi plots is that they facilitate the recognition of successive profile segments with different parameters. In this respect, Mudd et al. (2014) present a framework to identify the statistically most meaningful partition of a chi profile in segments of different steepness. However, we do not follow this approach because it allows only distinction of segments of varying steepness but the same concavity, whereas varying concavity is expected to be as important an attribute of the transient profiles we investigate. Our more empirical profile partition is based on visual inspection of the chi plots, at the benefit of tracking simultaneously steepness and concavity variations. As a result, three data types are obtained for each segment, namely (1) concavity, (2) steepness, and (3) the $z$ offset between successive segments.

Finally, while Eq. (2) shows that, at steady state, steepness $k_{s}$ is a direct function of rock uplift rate $U$ and an inverse function of erosion coefficient K (Snyder et al., 2000), it is also strongly correlated with profile concavity. Consequently, qualitative inferences on uplift rate are preferably drawn from normalized steepness values $\mathrm{k}_{\mathrm{sn}}$, obtained by recalculating steepness based on a reference concavity $\theta_{\text {ref }}$ fixed in general on the regional average of the observed concavities (Wobus et al., 2006).

\subsection{Age assessment: $R / S_{R}$ analysis}

The landscape index $S_{R}$ corresponds to the first derivative of the regression function linking a complex landscape metric $R$ to the natural logarithm of drainage areaA (Demoulin, 2011). The $R$ metric is calculable for fluvial catchments of every size and takes the form of a ratio of two-by-two differences between the normalized hypsometric integrals of the classical basin hypsometric curve $H_{\mathrm{b}}$, the drainage network hypsometric curve $H_{\mathrm{n}}$, and the trunk stream long profile $H_{\mathrm{r}}$ (Fig. 4), thus describing three nested morphological levels respectively indicative of the long-, middle-, and short-term components of the landscape response,

$$
R=\frac{\int_{0}^{1}\left(H_{\mathrm{n}}-H_{\mathrm{r}}\right) d l^{*}}{\int_{0}^{1}\left(H_{\mathrm{b}}-H_{\mathrm{n}}\right) d l^{*}}
$$

where $l^{*}$ is the dimensionless expression of length (for $\mathrm{H}_{\mathrm{r}}$ and $\mathrm{H}_{\mathrm{n}}$ ) or area (for $\mathrm{H}_{\mathrm{b}}$ ). This raw measure of $R$ is then corrected for the effect of the drainage network's branching level, the correction factor $1 / \sqrt{ } E$ relying on a measure of catchment elongation $E$, calculated as $4 A /\left(\pi L_{\mathrm{b}}^{2}\right)$, with $L_{b}=$ maximal length of the catchment, measured from its outlet (Demoulin, 2012; Demoulin et al., 2013).

The composite nature of $R$ is specifically aimed at capturing information about the stage reached by the drainage system's transient response to any perturbation corresponding to a relative base level lowering. As this response occurs primarily through the propagation of a wave of erosion travelling from the catchment outlet upstream through the drainage network, it makes the metric able to extract time information from the landscape shape. Demoulin (2011) shows that, following a base level lowering, the initial response stage of a preexisting drainage 
system leads to a rapid increase in $R$. Then, in the middle term $\left(>10^{4}-10^{5}\right.$ years $)$, the low courses of trunk stream and major tributaries having reached a new equilibrium, erosion proceeds at a progressively slower pace in the upper course of the trunk stream while it propagates simultaneously in an increasing number of tributaries and sub-tributaries, so that $R$ begins to decrease slowly with time. This behaviour allows the metric to be used as a chronometer for this stage of the evolution, which lasts a few million years until the system's response is completed in areas of moderate uplift and relief (Whipple, 2001; Whittaker et al., 2007).

Fig. 4. Description of the $R$ metric components for the Selinous river:

$1^{*}=1 / 1_{0}$, with $1_{0}=$ length of the river, cumulative length of its drainage network, and basin area respectively for $H_{\mathrm{r}}, H_{\mathrm{n}}$, and $H_{\mathrm{b}}: h^{*}=h / h_{0}$, with $\mathrm{h}_{0}=$ basin relief. $H_{\mathrm{b}}, H_{\mathrm{n}}$ and $H_{\mathrm{r}}$, are the hypsometric curves, i.e., cumulative distributions of altitudes, of the basin, the drainage network, and the trunk stream $\left(H_{r}\right.$ is therefore simply the trunk stream long profile). $E$ describes the basin's elongation.

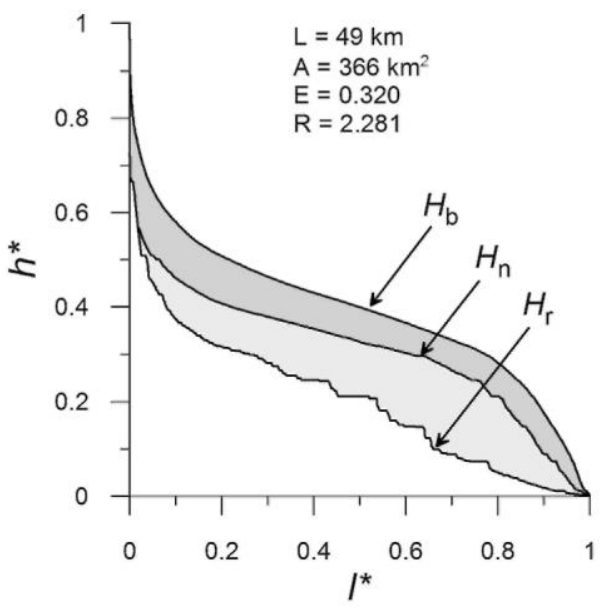

However, the size of the contributing drainage area $A$ is another major control on $R$, which thus cannot be used as a direct proxy for time. Fortunately, the logarithmic function linking the metric to $A$ is typical of each region of uniform uplift history, and Demoulin (2011) shows that the slope $\mathrm{S}_{\mathrm{R}}$ of the linear relation between $R$ and $\ln A$ is theoretically expected to evolve also continuously with time during the transient response to a perturbation. Therefore, $S_{R}$ may be used as another time indicator, free of basin size effect, and based on data from nine uplifted regions worldwide, Demoulin (2012) proposes an empirical quantitative relation linking $S_{R}$ to the age of uplift, reading

$t=0.009 \mathrm{SR}^{-4}$

with $t=$ time in million years.

However, the $R / S_{R}$ approach suffers from some limitations. In particular, it works best for en-bloc uplifted regions where a consistent relation may be estimated between $R$ and catchment size. As data of rivers with catchment larger than $150 \mathrm{~km}^{2}$ are needed to stabilize this relation, the study area should also be large enough to encompass several such rivers, including a few rivers with drainage area above $1000 \mathrm{~km}^{2}$. Because of the limited extent of the faulted blocks, such a condition is not met in the northern Peloponnese. However, Demoulin (2011) shows that, despite a higher sensitivity to the spatial distribution of the tributary network, deriving the $R=f(\ln \mathrm{A})$ relation from $R$ measurements at regular intervals along a single main river instead of using a sample of rivers of different sizes yields very similar $S_{R}$ values. In the northern Peloponnese, where we suspect that small contiguous areas experienced different uplift histories from east to west, the available range of river sizes was insufficient to calculate a reliable $R$-ln A relation in any of these areas. We thus calculated $\mathrm{S}_{\mathrm{R}}$ values based on $R$ profiles established along the main rivers in each area. A further advantage of this approach is its capacity to enhance potential streamwise changes in $S_{R}$ in relation with the $\mathrm{N}-\mathrm{S}$ succession of faulted blocks. Demoulin et al. (2013) show that the impact of other external controls on the relation between $S_{R}$ and time (e.g., direct controls on incision rate, such as rock resistance and climate, noise in the $R$ measurements caused by strongly non-dendritic patterns of tributary networks) is minor in most cases.

The practical method to obtain the hypsometric curves and integrals of basin, drainage network and trunk stream, needed to calculate the $R$ metric, is described in detail by Demoulin (2011). Owing to the good DEM resolution and quality, the induced uncertainty on $R$ is smaller than a few percents. In any case, its effect on $S_{\mathrm{R}}$ remains within the standard error on the index as calculated from the regression of $R$ on $\ln \mathrm{A}$. 
Fig. 5. East-west variation of the basin metrics (10 catchments, see Table 1).

A) Basin hypsometric integral. B) Same metric after removal of the basin size control on it. C) Shape descriptor of the basin hypsometric curve, best indicator, among basin metrics, of the progress of the landscape response to perturbation. D) Geophysical relief, expressed in metres. Distance is counted from the eastern end of the Gulf of Lechaion; see Fig. 2 for location.
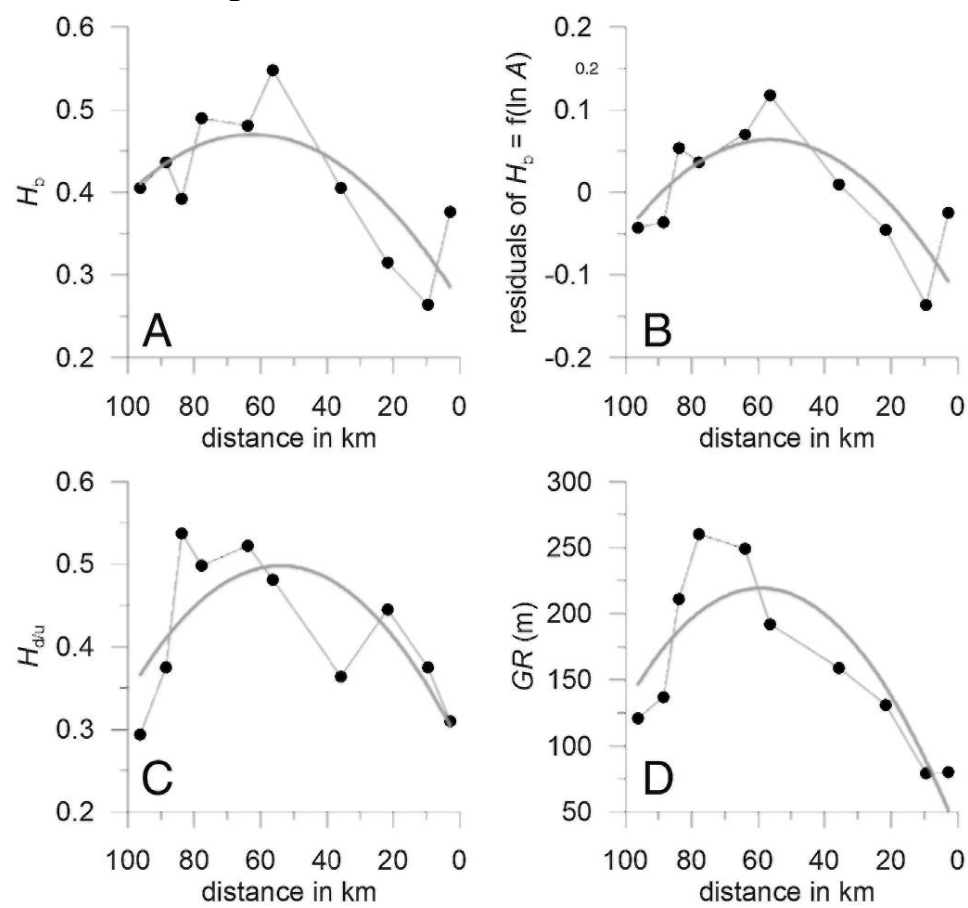

\section{RESULTS AND DISCUSSION}

The wealth and the variety of the collected morphometric data make it difficult to provide directly a comprehensive overview of the results, let aside their integrated interpretation. We thus first present, analyse, and discuss separately those results referring to whole catchments, trunk stream long profiles, and $R / S_{R}$ estimates of uplift timing. The 10 rivers we selected in this study are more or less regularly spaced from one end of the Gulf of Corinth to the other. They are also approximately of the same size $\left(20<L<50 \mathrm{~km} ; 65<A<370 \mathrm{~km}^{2}\right.$, see Table 1). Another requirement was that their watershed be not too elongated, so that their tributary network is developed sufficiently to allow meaningful $R$ measurements and $\mathrm{S}_{\mathrm{R}}$ estimates.

\subsection{Basin hypsometry}

\subsubsection{Hypsometric integrals}

The hypsometric integral values of the studied catchments range from 0.264 for the Raizanis in the east to 0.548 for the Krios in the central sector of the rift's southern border (Table 1). Although such variations certainly contain significant information about controls on $H_{\mathrm{b}}$, it does not make much sense to discuss the absolute values of the integrals in terms of landscape youth or maturity, because almost all catchments are comprised of several differently uplifted blocks, whose contrasted elevations and relative areas strongly affect integral value and shape. The analysis of the E-W changes in $H_{\mathrm{b}}$ is more instructive. In spite of the effect of differential block uplift, which affects to some degree almost all catchments, $H_{\mathrm{b}}$ shows a weak but significant negative correlation with drainage area A $(p=0.072)$. The existence of such a correlation is generally thought to indicate a transient state of landscape disequilibrium (Chen et al., 2003; Demoulin et al., 2013), which is consistent here with the characteristics of the river long profiles (see below). Interestingly, using the residuals of the $H_{\mathrm{b}}=f(\ln \mathrm{A})$ regression improves the general shape of their observed E-W changes (Fig. 5A, B), making it highly consistent with the E-W curve of other metrics (Fig. 5). The analysis of E-W changes in the values and residuals of $\mathrm{H}_{\mathrm{b}}$ points to positive residuals, corresponding to the highest values of the integral, for streams 3 to 6 in the westcentral part of the rift border (from Selinous to Krios, Fig. 5B). This peak in $H_{b}$ values in the Aegion-Derveni sector is a first morphometric indication that landscape rejuvenation there results from the most recent and/or strongest rock uplift, and subsequent drainage network incision. Elsewhere, the distinctly larger negative residual and anomalously low integral of the Raizanis primarily result from the presence of a small topographic basin in its upper catchment. 


\subsubsection{Hypsometric curve shape}

The observed $\mathrm{H}_{\mathrm{d} / \mathrm{u}}$ values range from 0.294 for the Phoenix to 0.537 for the Selinous, with E-W variations mimicking those of basin integral $H_{\mathrm{b}}$ (Fig. 5C). Having checked that there is no significant control of drainage size on $\mathrm{H}_{\mathrm{d} / \mathrm{u}}$ and that this metric is also largely not redundant with $\mathrm{H}_{\mathrm{b}}$, we analyse the spatial distribution of catchment $\mathrm{H}_{\mathrm{d} / \mathrm{u}}$ in the following way. By definition, high $\mathrm{H}_{\mathrm{d} / \mathrm{u}}$ values are obtained when the average elevation of the catchment's lower half is not much lower than that of its upper half, indicating that only a limited part of the valley network has been incised since a recent base level lowering. Conversely, lower $\mathrm{H}_{\mathrm{d} / \mathrm{u}}$ values, chiefly resulting from decreased $\mathrm{H}_{\mathrm{d}}$ (Fig. 3A), betray the upstream progression of the erosion wave and the subsequent valley widening witnessing a more advanced stage of the landscape response to the perturbation. In this sense, the $\mathrm{E}-\mathrm{W}$ distribution of $\mathrm{H}_{\mathrm{d} / \mathrm{u}}$ values indicates a most recent uplift in the Aegion-Derveni central sector, confirming the conclusion drawn from $H_{\mathrm{b}}$.

Fig. 6. Typical streamwise evolution of basin hypsometric integral $H_{b}$ (black dots) and hypsometric shape descriptor $H_{d / u}$ (grey open squares). The latter curve is displaced down by 0.1 to make the graphs clearer. A) Trikalitikos. B) Krathis. In each case, the evolution is best fitted by a second-order polynomial. Vertical lines locate faults; vertical grey bars correspond to knickzones in the river profile.
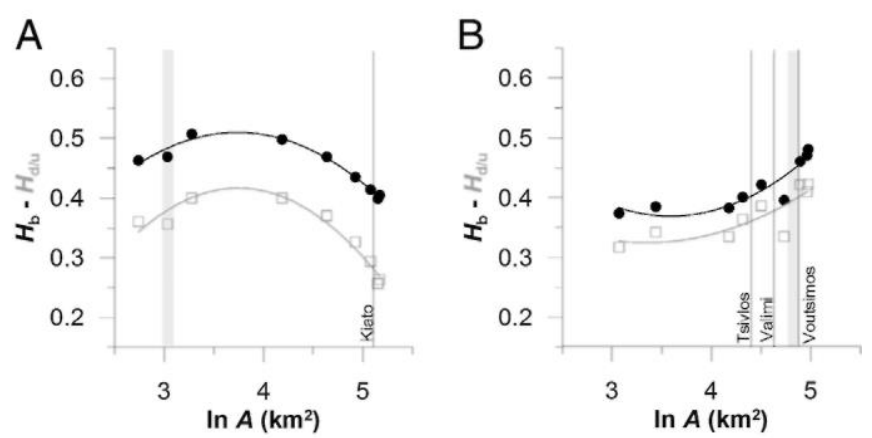

Fig. 7. Graphs of the streamwise variations in $H_{b}$ shape $(A-C)$ and of the probability density functions of the corresponding basin pixel elevations $(B-D)$. Graphs $A$ and $B$ refer to the Selinous; $C$ and $D$ to the Xerias. Numbered arrows in graphs $A$ and $C$ indicate the successive phases of the downstream evolution of $H_{b}$. Position of the sampling points along the river is given in distance from the source.
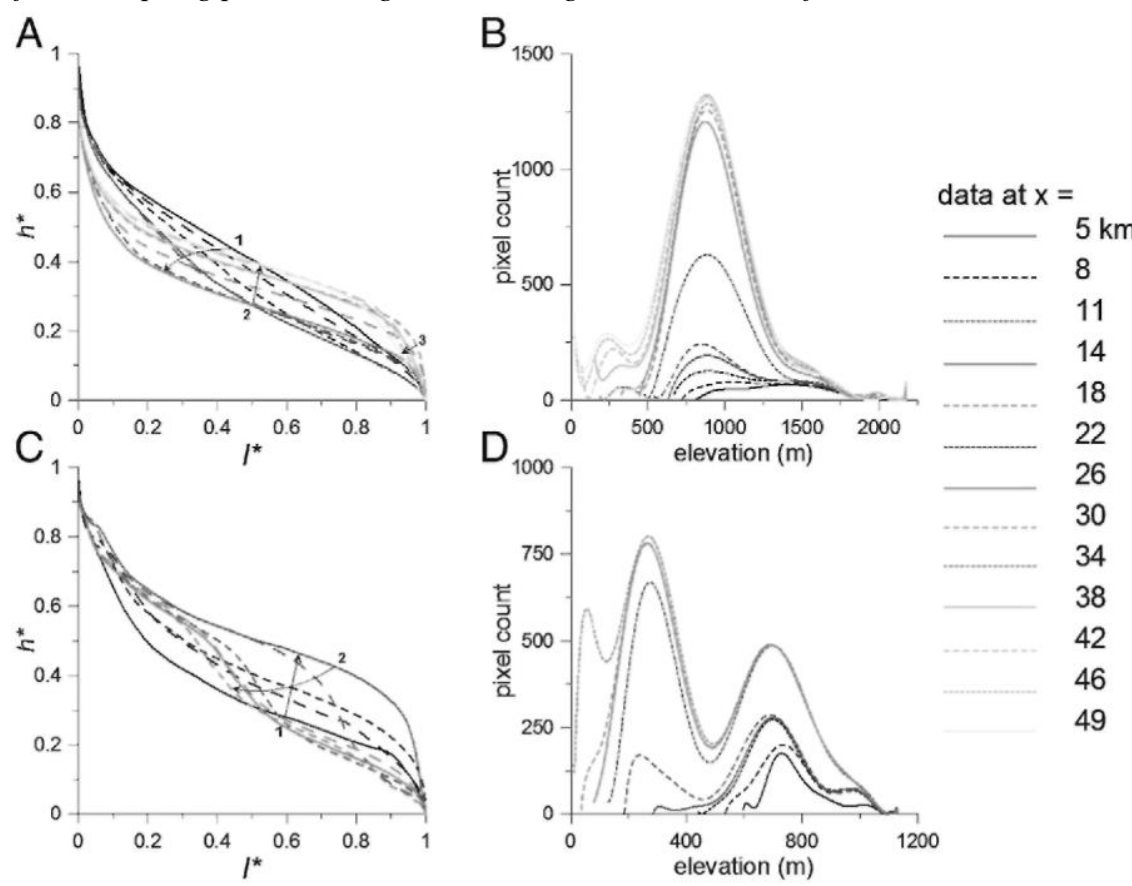


\subsubsection{Streamwise changes in hypsometry}

Beyond overall description of basin hypsometry, we tentatively explored the potential of $H_{\mathrm{b}}$ and $\mathrm{H}_{\mathrm{d} / \mathrm{u}}$ long profiles for morphotectonic purposes. These profiles describe the streamwise changes in fractional $H_{\mathrm{b}}$ and $\mathrm{H}_{\mathrm{d} / \mathrm{u}}$ calculated at stepwise increasing distance $L$ of the trunk source.

Two main characteristics of the obtained profiles deserve attention (Table 1, Fig. 6). First, $H_{\mathrm{b}}$ and $\mathrm{H}_{\mathrm{d} / \mathrm{u}}$ long profiles are very similar to each other for most basins. This is interpreted as a hint that streamwise changes of $H_{\mathrm{b}}$ and $\mathrm{H}_{\mathrm{d} / \mathrm{u}}$ respond to more general factors than only a drainage network response to recent tectonic activity. Indeed, the drainage network pixels represent only an average $1.7 \%$ of the total number of pixels in a basin, and even taking into account the associated valley bottom pixels, they appear unable to exert the effect we expected on $H_{b}$ and $\mathrm{H}_{\mathrm{d} / \mathrm{u}}$. The $H_{b}$ and $\mathrm{H}_{\mathrm{d} / \mathrm{u}}$ long profiles depend on an intricate mix of overall basin topography, produced by the inherited and tectonic components of morphogenesis, and river incision features that we can hardly hope to unravel in most cases. At best, they unveil static data about basin hypsometry, revealed by recurrent patterns of $H_{b}$ and $\mathrm{H}_{\mathrm{d} / \mathrm{u}}$ that make their second important characteristic.

Two main patterns are identified, where the index long profiles are best fitted by second-order polynomials, either convex or, less often, concave upward (Fig. 6). The basin hypsometric features underlying such patterns are most easily identified from visualizing changes in the probability density function (pdf) of basin elevations with increasing $L$ (Fig. 7). However, these streamwise variations of elevation pdf do not tell us anything about the origin (erosive or tectonic) and age (recent or inherited) of the distribution of elevations. In summary, the morphotectonic usefulness of $H_{b}$ and $\mathrm{H}_{\mathrm{d} / \mathrm{u}}$ profiles appears rather limited.

\subsection{Geophysical relief}

The values in metres and the normalized figures of $G R$ are highly correlated. We thus base the discussion hereafter on the metric values of $G R$ (Table 1). They range from $79 \mathrm{~m}$ for the Raizanis to $260 \mathrm{~m}$ for the Kerynitis (Table 1, Fig. 2). Similarly to $H_{\mathrm{b}}$ and $H_{\mathrm{d} / \mathrm{u}}, G R$ is maximum for basins 3 to 6 in the west-central sector of the study area and decreases west- and, still more, eastward, with the lowest values for basins draining to the far east of the Corinth gulf (Fig. 5D).

Based on a more appropriate assessment of the initial basin topography, $G R$ is assumed to be a more meaningful metric than $H_{\mathrm{b}}$, to which it is significantly correlated $\left(r^{2}=0.51 ; \mathrm{n}=10 ; p=0.010\right)$. However, while basin integral $H_{\mathrm{b}}$ is related to the remaining uneroded rock mass of a basin, $G R$ quantifies the rock mass removed by erosion. As such, both metrics would be expected to be anti-correlated but, surprisingly, the obtained correlation is direct (Fig. 5A, D). This sheds doubt on the common belief that $H_{\mathrm{b}}$ values are primarily reflective of the stage reached by the landscape response to a base level lowering, and suggests that, in the case of spatially variable uplift, the first control on both $G R$ and $H_{b}$ is uplift rate, which acts on erosion rate $(G R)$ and total rock volume above base level $\left(H_{b}\right)$ in the same sense. This is further supported by the strong link observed between $G R$ and actual basin relief. This link is significantly weaker for $H_{\mathrm{b}}$ and, still more, for $\mathrm{H}_{\mathrm{d} / \mathrm{u}}$, from which we conclude that, beyond uplift rate control, $\mathrm{H}_{\mathrm{d} / \mathrm{u}}$ is the metric most sensitive to, and therefore indicative of, the progress of landscape incision in response to uplift. In other words, among catchment metrics, $G R$ and $\mathrm{H}_{\mathrm{d} / \mathrm{u}}$ are probably the best indicators of, respectively, uplift rate and progress of erosion (and hence age of the triggering event), whereas the interpretation of $H_{\mathrm{b}}$ is generally more obscure. These metrics consistently point to the AegionDerveni west-central sector of the Péloponnèse northern border as being most actively and most recently uplifted.

The E-W variations in $\mathrm{GR}_{\text {network }}$ values, which quantify the drainage network mean incision with respect to the reference summit surface and are thus a still better proxy than $G R$ to the amount of triggering uplift, closely mimic the corresponding variations of GR (Table 1). They suggest a maximum 410-420 m uplift and incision in the central sector of the study area since the reference time. We recall that, as the reference summit surface incorporates minor ridges belonging to the top surface of the Plio-Quaternary deltas, the reference time is that of incision within these deltas, which most probably started in response to the oldest uplift episode identified by the morphometric analysis.

Noteworthy is also that, while the ratio $G R / G R_{\text {netwoyk }}$ amounts to $60-65 \%$ for all basins in the western and central sectors of the northern Peloponnese, it increases to $70-85 \%$ for the Asopos, the Raizanis, and the Xerias. This indicates that denudation of interfluves is going to catch up with river erosion in the east, providing further evidence that the landscape response to the tectonic signal is more advanced, i.e., the signal is older there than elsewhere along the coast. 
Fig. 8. $\chi$ plot of the Kerynitis long profile. Whole river plot in black (+ linear fit as thin black line). The best fit $\chi$ plot is unable to straighten the profile, where three successive concave (SI and S2) or convex (S3) segments are visually easily distinguished. Straightening of the partial $\chi$ plots SI, S2 and S3 (left part of the diagram, in distinct grey tones) is much better and provides individual concavity values ( $\mathrm{m} / \mathrm{n}$ of best fits). The slope of the individual plots corresponds to the segments' raw steepness (normalized steepness in Table 1 has been calculated with a reference concavity of 0.5). The insets enlarge the plots' intersection to illustrate how the vertical offset is obtained from the vertical spacing between the linear fits of the segments at their intersection point Note also that the $\chi$ plot scale is different for the successive segments, and they have been shifted laterally in order to be connected.

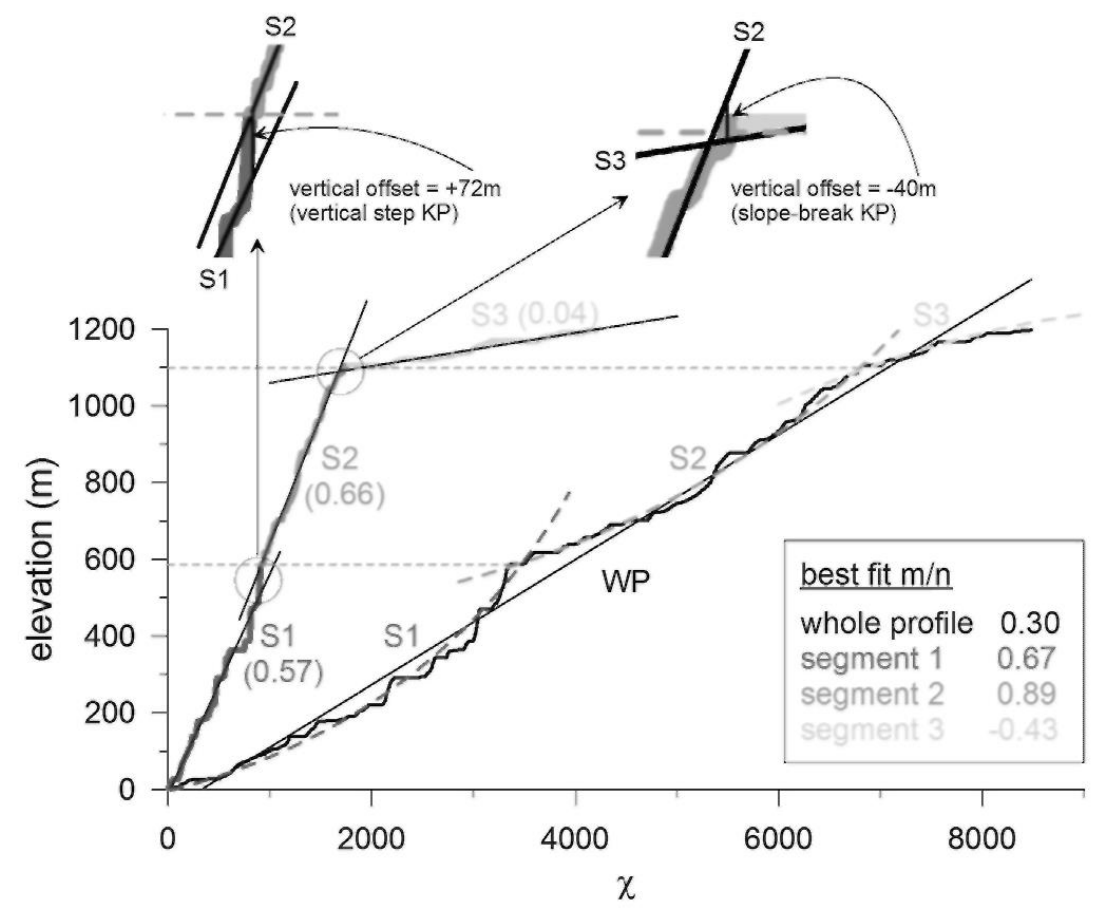

\subsection{Chi plots}

\subsubsection{Profile segmentation}

Profile segmentation was carried out by visual inspection of the chi plotof the whole river. Indeed, if several segments are present, the overall chi plot, theoretically supposed to tend toward a straight profile, displays a succession of distinct concave or convex reaches (Fig. 8), for which we determined specific parameters from individual sub-plots. In most instances, we distinguished three segments per river profile (Table 1) but, in seven out of the 10 profiles, the upstream segment was limited to the initial $2-2.5 \mathrm{~km}$ that the river descends rapidly from peak areas down to elevations $>1000 \mathrm{~m}$. Such short upstream segments determined solely by topographic conditions and often showing negative concavities have not been included in the analysis.

The principal segment separation, in most cases independent of active fault location, is observed at distances from the outlet that are linearly dependent on drainage area $\left(r^{2}=0.59, \mathrm{n}=9, p=0.0078\right)$. It results from upstream propagation of erosion in the drainage system and most probably corresponds to one single event of relative base level lowering or uplift acceleration throughout the study area. This is especially clear for the rivers of the western and central sectors, where it occurs systematically at 51-57\% of the total river length (measured from the outlet), while it proceeded slightly more upstream in the rivers of the eastern sector (Fig. 9). 
Fig. 9. Limits between $\chi$ plot segments, i.e., knickpoints or knickzones in the river profiles (black bold bars) and between $R / S_{R}$ segments (white bold bars ). Faults mentioned in Section 4.5 -Sf: Selinitika fault Aef: Aegion fault Akf: Akrata fault Df: Derveni fault Sif: Sithas fault Xf: Xylokastro fault (on-and offshore). WHf: West Heliki fault EHf: East Heliki fault P-Mf: Pirgaki-Mamousia fault

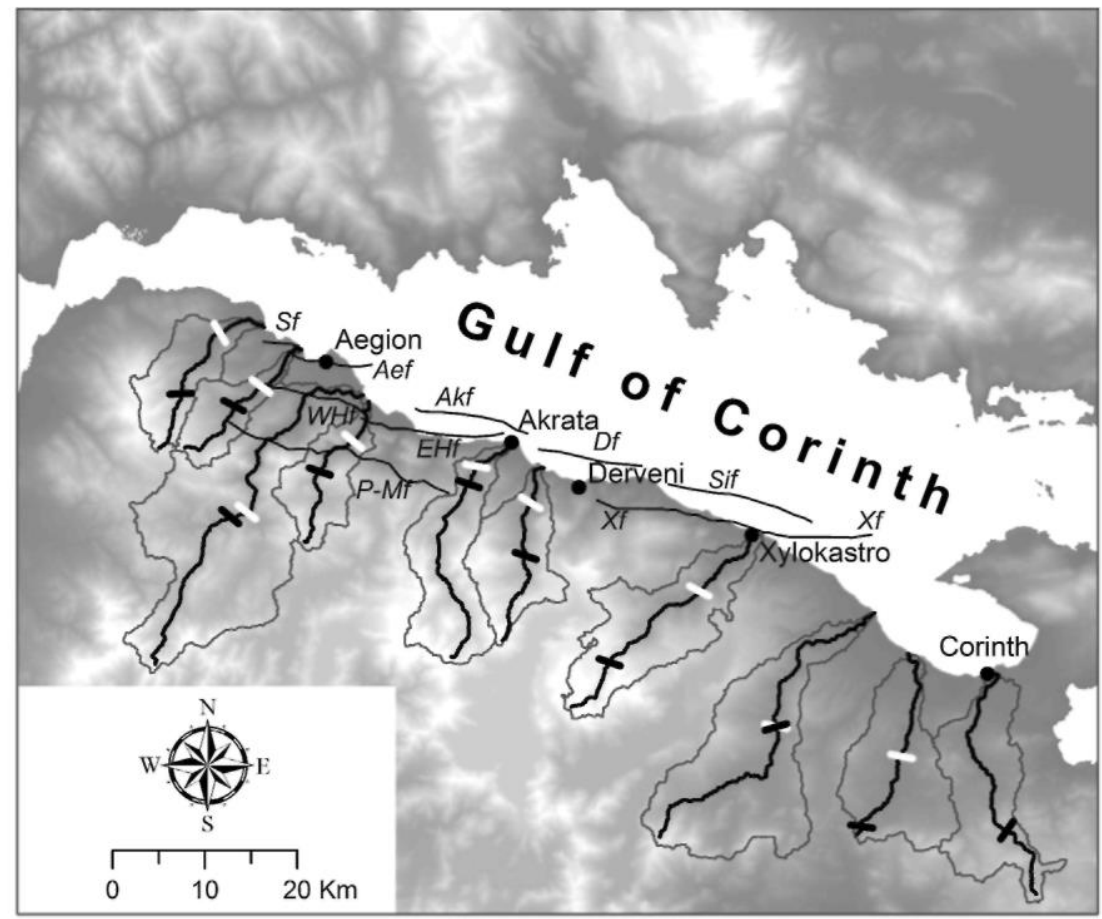

Fig. 10. East-west variation of the uplift rate $\left(k_{s n}: A\right.$ and $\left.C\right)$ and time $\left(S_{R}: B\right.$ and $D$, with error bars) indicators for the downstream $(A$ and $B)$ and upstream $(C$ and $D)$ segments of the river profiles $(10$ catchments, see Table 1 ). E-W trends are shown in grey. Stars in $(B)$ denote two outliers: (Pho.) the Phoenix catchment, not yet reached by the uplift wave; (Sel.) the Selinous catchment much larger than all others, imposing faster initial evolution of $S_{R}$. Distance is counted from the eastern end of the gulf of Lechaion; see Fig. 2 for location.
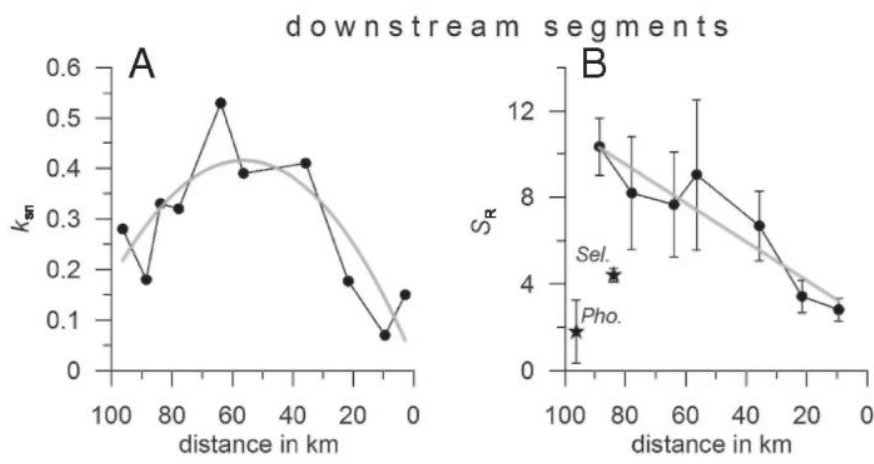

upstream segments
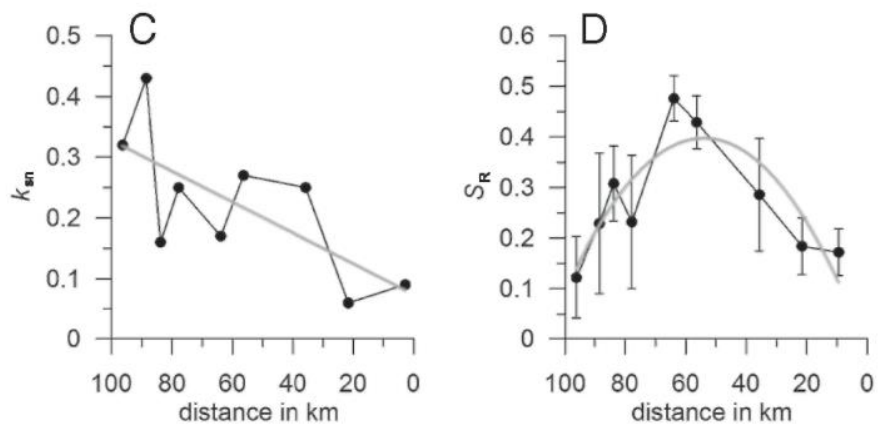
Fig. 11. Comparative E-W distribution of geophysical relief values GR (grey triangles) and steepness $k_{s n}$ of the downstream segments (black dots). The $k_{s n}$ curve indicative of uplift rate in the latest phase is slightly shifted eastward with respect to the GR curve. Note also that $E-W$ relative variations in $G R$ and $k_{s n}$ are remarkably similar. Distance is counted from the eastern end of the gulf of Lechaion; see Fig. 2 for location.

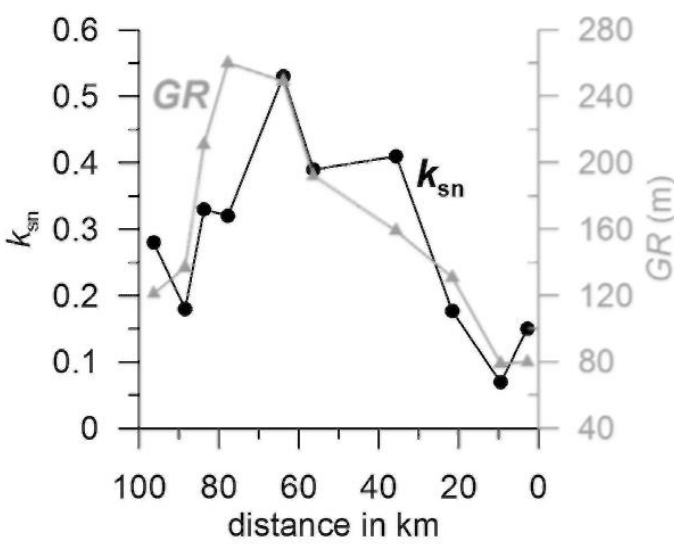

\subsubsection{Concavity}

In a majority of rivers, the downstream segment shows a lesser concavity than the one immediately upstream (Table 1), thus bearing witness to a more recent evolution, as expected when the river response to base level perturbations is advected headward. However, the concavity values are highly variable from one river to the other and no clear pattern emerges from the whole, probably because a main control is local variations in bedrock resistance to erosion. This certainly explains also why downstream segments are in a few cases more concave on weak syn-rift alluvial fan and fan delta sediments than the corresponding upstream segments cut in harder basement limestones. Vassilakis et al. (2007) calculate from $\log$ S/logA plots the concavity of four rivers analysed here (Krathis, Krios, Trikalitikos, and Asopos). Although some values differ between the two studies, they are similarly ranked. In any case, thanks to the use of less noisy data and profile segmentation, the values derived from our chi plots are more reliable.

\subsubsection{Steepness}

The $k_{s n}$ values presented in Table 1 were calculated for $\theta_{\text {ref }}=0.5$. Small $k_{s n}$ values $(<1)$ result from having expressed $A$ and $A_{\text {zet }}$ in $\mathrm{km}^{2}$ rather than in $\mathrm{m}^{2}$ in Eqs. (5) and (6), and need to be multiplied by $\left(10^{6}\right)^{0.5}=1000$ for comparison with most published data.

Considering first the downstream segments, which record the drainage system's response to the most recent uplift phase, $k_{s n}$ values are maximum (0.39-0.53) for rivers of the central sector (Krathis, Krios, and Trikalitikos), intermediate (0.18-0.33) for rivers of the western sector, and lowest (0.07-0.18) in the east (Fig. 10A). This E-W distribution is very similar to that of most basin metrics, and especially to that of $G R$. Yet, like $G R$, river profile steepness is highly dependent on uplift rate. Its observed variations thus confirm that, in particular during the most recent phase of activity, the uplift was most intense in the central sector of the rift's shoulder and lowest in its eastern part. However, the superposition of the E-W curves of $G R$ and downstream $/ \mathrm{c}_{\mathrm{sn}}$ shows that the peak of the $k_{s n}$ curve is slightly eastward shifted with respect to the $G R$ peak (Fig. 11), suggesting a recent displacement of the zone of maximum uplift. We crudely estimate what is called here 'recent' from the length of the involved downstream segments (10-25 $\mathrm{km}$ for $100-200 \mathrm{~km}^{2}$ catchments). Indeed, several studies derived relationships between the average propagation rate of an erosion wave and drainage area that consistently point to rates around $1 \mathrm{~m}$ year ${ }^{-1}$ in rivers with $A \sim 100 \mathrm{~km}^{2}$ and time scales of $10^{3}-10^{4}$ years (Bishop et al., 2005; Loget and Van Den Driessche, 2009; Ye et al., 2013). According to such relations, the last uplift phase in the northern Peloponnese would have started some 10-20 ky ago.

Because the present-day coastline cuts obliquely the rift border faults, each river's downstream segment is inscribed in a particular fault block. Interpreted that way, the highest steepness values characterize downstream river reaches incising the footwall of the Krathis fault and the relay zone between the East Heliki and Derveni faults (Hemelsdaël and Ford, 2015), as well as the footwall of the onshore Xylokastro fault, suggesting that these faults underwent the highest Holocene slip rates. By contrast, the location of the $G R$ peak indicates that, in the middle term (a few $10^{5} \mathrm{ka}$ ), average slip rate was highest on faults located slightly more to the west.

The chi plot segments situated immediately upstream of the previous ones show steepness values ranging from 
0.06 to 0.43 that tend to increase from east to west (Fig. 10C). This trend points to maximum uplift in the western part of the rift $\left(k_{s n}>0.30\right)$ during this phase of regional evolution. Intermediate steepness values $(0.16<$ $\left.k_{s n}<0.27\right)$ suggest more moderate uplift for the largest part of the northern Peloponnese, except in the easternmost area where low steepness $\left(0.06</ \mathrm{c}_{\mathrm{sn}}<0.09\right)$ points to minor uplift.

Finally, a comparison between steepness values of the downstream river segments and those upstream should give clues about the temporal evolution of uplift rates. However, profile steepness not only depends directly on $U$, but also is an inverse function of $K$, and in particular of substrate erodibility (Eq. (2)). Three different lithological types crop out in the study area (Fig. 1): relatively resistant limestones of the Mesozoic basement in the upstream part of most catchments; poorly to mildly cemented coarse conglomerates of the Early and Middle Quaternary alluvial fans and proximal Gilbert deltas (essentially made of limestone cobbles) prevailing in the middle and downstream reaches of the western rivers; poorly cemented sand- and siltstones in the more distal parts of the deltas, predominating in the downstream part of the central and eastern catchments. However, different materials do not necessarily induce significant change in erosion rate because it involves two opposite controls on erosion of the river bed that more or less cancel each other. Channel bed erodibility is the first of these controls and may be estimated through the tensile strength $\sigma_{t}$ of the rock. Limestone rock and the limestone cobbles making the bulk of the conglomerates show higher $\sigma_{t}$ values than poorly cemented sand-and siltstones, Sklar and Dietrich (2001) showing that erosion rate $E$ scales with $\sigma_{\mathrm{t}}^{2}$. The second lithological control on erosion rate is erosivity of the bedload, which increases non-linearly with grain size $D, E$ scaling here with $\sim D^{2}$ (Sklar and Dietrich, 2001). Therefore, the coarse bedload eroding resistant limestone rock or conglomerates in the western catchments has more or less the same erosional efficiency as the finer bedload eroding less resistant sand- and siltstones in the eastern catchments, resulting in insignificant net change in vertical erosion rate between the two settings. However, the net lithological control on erosion rate may become higher in the case when bedload and channel bedrock are different, and coarse bedload delivered by the Mesozoic basement in the upstream catchment of rivers should be more efficient in eroding downstream reaches in weaker sand- and siltstones. This occurs mainly in the downstream segments of the eastern rivers (Asopos, Raizanis, and Xerias), where low steepness values might result from low $U$, high $K$, or from their combined effect. However, possibly because the control of $K$ on steepness is damped by sorting and attrition effects on bedload grain size with distance, the lower segments of the $\mathrm{I}<$ rios and Trikalitikos do not show the low steepness expected from their lithological conditions. This not only confirms the minor role of bedrock resistance to erosion in the long-term process of river incision (Roberts and White, 2010; Whittaker and Boulton, 2012; Beckers et al., 2014), but also shows that, except in the far west of the study area, the current episode of uplift is more intense than the previous one.

\subsubsection{Offset between segments}

A last parameter that may be considered in the chi plot analysis is the vertical offset between the best fit lines of successive profile segments. Profile discontinuities described as vertical step knickpoints by Lague (2014) display positive segment offsets (observed in the upstream direction), whereas negative offsets correspond to slope-break knickpoints and knickzones (Fig. 8). While the amounts of negative offsets have no explicit meaning, positive ones provide a good estimate of the relative height of steep knickpoints. The maximum values of 189 and $113 \mathrm{~m}$ are obtained for the Krathis and Krios rivers in the central sector of the Péloponnèse border, between Akrata and Derveni. The Krathis knickpoint corresponds to a deep gorge reach cut through Mesozoic limestones and showing an average channel gradient of $-15 \%$. Similar spectacular gorges are also present to the west in an adjacent small stream (the Ladopotamos) and in the Vouraikos, where these streams cross the proximal part of the Mamousia fault's footwall. As the penultimate episode of uplift occurred significantly later in this sector than elsewhere (see Section 4.4.2), we suggest that gorges and high knickpoints might result from the current erosion wave having caught up and superposing there with the previous one, which migrates less rapidly in harder rocks.

\section{4. $R / S_{R}$ analysis \\ 4.4.1. Regional analysis}

From the theory of the $R / S_{R}$ approach (Demoulin, 2011), a strong correlation is expected between $R$ and basin size for the catchment/subcatchment population of a region of homogeneous uplift history. Testing for the existence of such a correlation is therefore one way to determine whether uplift timing was uniform across a particular area. Although the range of catchment size analysed here is rather limited, it extends toward sufficiently large basins to allow evaluation of this hypothesis. Based on the $R$ value at the outlet of the sampled rivers $(n=10)$, we observe no correlation with basin size, demonstrating that the successive uplift episodes occurred at different times in different sectors of the southern shoulder of the Corinth rift. 
Fig. 12. Streamwise evolution of the $R$ metric (and $S_{R}$ index) along the 10 studied rivers, showing the typical

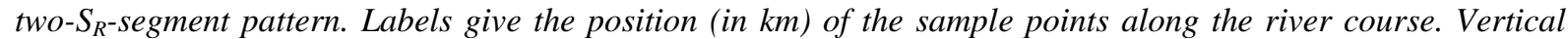
lines locate faults. Wide grey bar locate knickzones in the river long profiles. 1: Phoenix. 2: Meganitis. 3 : Selinous. 4: Kerynitis. 5: Krathis. 6: Krios. 7: Trikalitikos. 8: Asopos. 9: Raizanis. 10: Xerias.
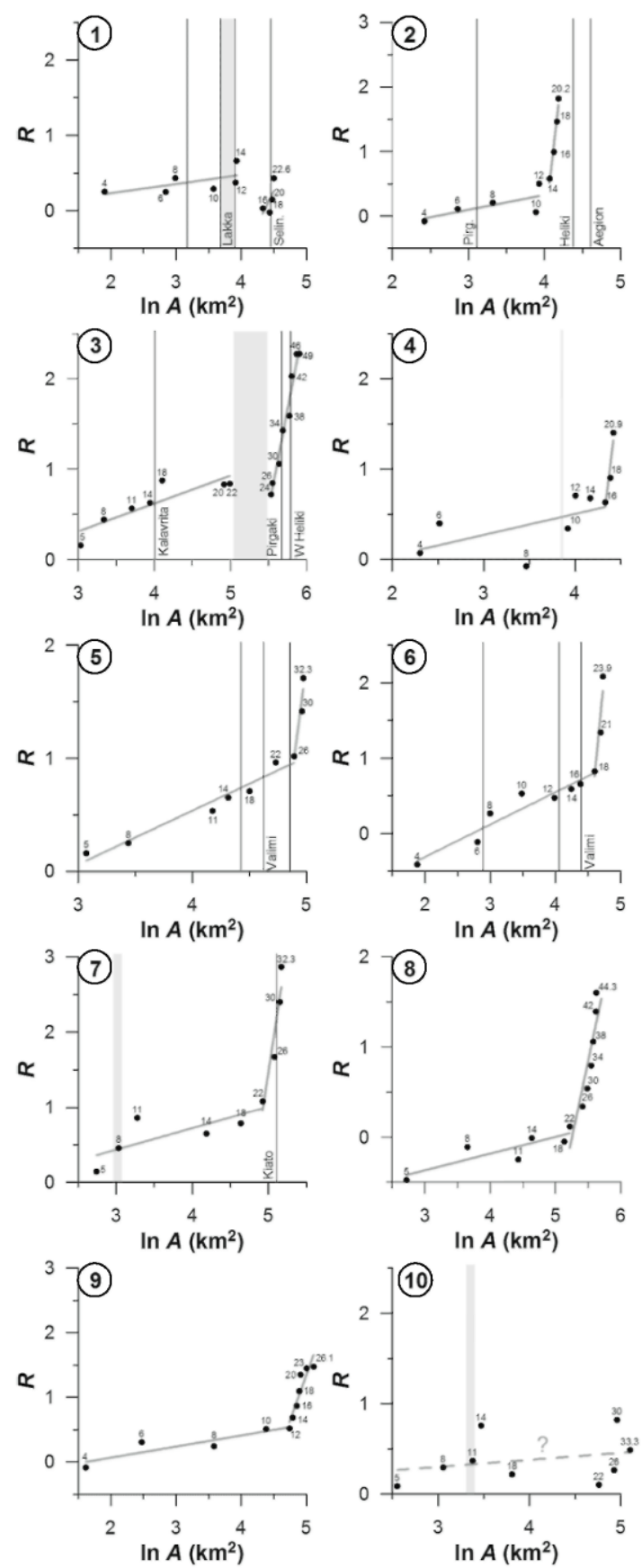

4.4.2. Streamwise analysis

Analysis of the rivers' $R$ profiles is much more conclusive, most of them showing a typical succession of two segments with distinct $R$ - $\ln A$ relations (i.e., distinct $\mathrm{S}_{\mathrm{R}}$ ) (Fig. 12). The resulting picture of two identifiable uplift episodes in each catchment is remarkably consistent with that provided by the independent analysis of chi plots and brings new insight into the temporal characteristics of these episodes.

As for chi segments, the $R$ segment separation is observed at distances from the outlet that are linearly dependent on drainage area $\left(r^{2}=0.91, \mathrm{n}=9, p=0.0000\right)$, confirming that this separation corresponds to the same event throughout the study area. However, although basin size controls the distance at which changes in $R$ have propagated, the absence of correlation with the corresponding $S_{R}$ values indicates that it does not affect this index and its temporal meaning. The distance travelled by the upstream propagating changes in $R$ is 
systematically smaller by a few kilometres than the corresponding distance run by the knickpoint migrating in the main stem (Fig. 9), underlining that the whole drainage network and the basin topography need more time than the main stem to respond to a perturbation.

The dominant characteristic of downstream $S_{R}$ values (Table 1), indicative of the most recent uplift episode, is that they are all very large (between 1.8 and 10.3), much larger than the values recorded elsewhere, which never exceed 1 (Demoulin, 2012; Demoulin et al., 2013). The only circumstance in which comparably high $S_{R}$ values were observed was when the $R / S_{R}$ analysis was applied to synthetic landscapes (Croissant, 2012). In that study, a topography defined by low-amplitude cosine functions was uplifted in order to analyse the behaviour of the $S_{R}$ index with time. The results show that $S_{R}$ values larger than 1 always characterize the first stage of the landscape response, when a drainage network has first to be created, and that they lower to real-world values once the network is fully established. The topographic setting in which river incision developed when Late Pleistocene uplift caused emergence of the northern Peloponnese shore is very similar (though not exactly because the stream network in the emerged land was partly determined by the downstream prolongation of the preexisting rivers), showing that downstream $S_{R}$ values in the Peloponnese conform with their modelled equivalent. However, beyond the observation that $S_{R}$ shows a power law decrease with time, no quantitative relation $S_{R}=$ $f(t)$ is available so far for such a case, and we only discuss the relative timing of this episode of uplift from east to west. With the exception of the slightly outlying Selinous value, the analysed basins display a consistent picture of downstream $S_{R}$ regularly increasing from east to west (Fig. 10B), suggesting that the last phase of accelerated uplift started earlier in the east and propagated westward. The comparatively small value of the westernmost Phoenix basin indicates that the uplift phase reached it only very recently, already allowing distinction of a particular segment in its $R$ profile but having not yet fully completed the accompanying increase in $\mathrm{S}_{\mathrm{R}}$.

The lower, more classical upstream $S_{R}$ values (Table 1) attest the response of the landscape to an older uplift phase. However, even there is data interpretation not that straightforward because response to uplift involved land emergence also in that time and the $t=f\left(S_{R}\right)$ relation of Demoulin (2012) consequently might not hold. Whereas the absence of tributary network in a small tract of virgin land added to a catchment has a strong initial impact on the catchment's $R$ and $\mathrm{S}_{\mathrm{R}}$ values, its progressive buildup makes this effect dwindle away in parallel with the time evolution of the catchment metrics, so that the effect vanishes after some time. However, because the percentage of emerged areas and their impact on the metrics are variable from catchment to catchment, ages derived from upstream segment $S_{R}$ may still be variably underestimated and the E-W variations of the index have themselves to be interpreted with caution.

Nevertheless, the E-W distribution of upstream $S_{R}$ values (Fig. 10D, Table 1) displays a marked peak in the central sector that cannot be ignored. Narrow use of Eq. (8) suggests that the corresponding older uplift event began around 200-270 ka in this central sector whereas it dates back to more than $1 \mathrm{Ma}$ in the east and the west. In other words, the western and eastern sectors did not record the $270 \mathrm{ka}$ uplift phase, in the sense that they did not undergo any increase in uplift rate at that time. As the percentage of uplift-dependent emerged land was particularly large in the Krathis and Krios catchments, its long-lasting impact on their $S_{R}$ value is however certainly still non-zero, making the calculated 200-270 ka a default estimate. Based on the comparison between the $S_{R}$ values after -20 ka when partial land emergence and creation of new downstream drainage branches are involved (downstream $S_{R}$ in Table 1) and the results of Croissant (2012) when a complete drainage system has to be created from scratch, we estimate to $100-150 \mathrm{ka}$ the initial period needed before the $S_{R}$ values under consideration started to evolve with time following Eq. (8). This yields a more realistic morphometric age around 350-400 ka for this penultimate uplift phase. A conservative interpretation of the upstream $S_{R}$ data is thus that an Early Pleistocene uplift phase affected the entire northern Peloponnese border and that it was traceably overprinted by a middle Middle Pleistocene phase of increased uplift rate only in the central sector. This coincides with the peak in $\mathrm{H}_{\mathrm{d} / \mathrm{u}}$ observed in the same sector (Fig. 5D), which also suggests that the landscape is younger there than elsewhere along the rift.

\subsection{Synthesis of the results}

Synthesizing the morphometric results presented above, we identify the following characteristics of the recent uplift history of the northern Peloponnese:

- As segment limits in the chi plots and $R$ profiles are most generally not coincident with the location of faults and associated lithological contrasts; they may safely be interpreted as marking the upstream points reached by an erosion wave propagating in the drainage system.

- The topography of each studied catchment records two successive uplift episodes. Moreover, the older observed episode is distinctly younger in the central Akrata-Derveni area than to the east and the west, so that a total of three separate uplift phases are identified. The older topography on which these three uplift phases 
successively imposed their mark is barely preserved in the form of small headwater chi-plot segments.

- Quantitative age estimates of the latest uplift episode cannot be provided by downstream $S_{R}$ values because they incorporate the creation of downstream extensions of the drainage network when uplift caused a strip of coastal land to emerge. However, E-W variations in downstream $S_{R}$ show that this uplift started in the east and propagated westward (Fig. 10B). Crude absolute timing may be inferred from the length of the downstream chi plot segments, i.e., from the distance travelled by the knickpoints created by this uplift phase, and suggests an age of 10-20 ka. Metrics related to basin scale do not yet contain information about this recent perturbation.

- Age estimates of the older uplift episodes may be inferred from various morphometric sources. Basin-scale metrics show that the older observed phase of uplift is of oldest age in the east of the study area, of intermediate age in the west, and of youngest age in the central Akrata-Derveni sector. We calculate from upstream segments' $\mathrm{S}_{\mathrm{R}}$ that, with a corrected age of 350-400 ka, this uplift phase in the latter sector is temporally distinct from the > 1 -Ma-old one in the two other sectors. This is consistent with the maximum chi segment offsets observed in the valleys of the Akrata-Derveni area, where the age estimate is further supported by comparing the $\mathrm{GR}_{\text {ne }}$ tworkbased estimate of uplift (up to $414 \mathrm{~m}$ ) with independent uplift rate estimates (1.0-1.3 mm year ${ }^{-1}$; De Martini et al., 2004; McNeill et al., 2005; Vassilakis et al., 2007). This yields an approximate age of 320-415 ka.

- The morphometric data show uplift rates were highest in the west during the Early Pleistocene uplift phase (Table 1, upstream $k_{s n}$ and $H_{b}$ ). Then, after the Middle Pleistocene phase affected only the Akrata-Derveni area (Table 1, upstream $S_{R}$ ), the Holocene phase continues to impose maximum uplift on an east-central sector of the rift shoulder (Table 1 , downstream $k_{s n}, G R$, and $H_{\mathrm{b}}$ ). In this zone, $\mathrm{GR}_{\text {network }}$ values suggest that the Middle Pleistocene and Holocene phases were combined to produce total uplift of 400-500 m. Vertical offsets between chi plots' segments indicate uplift rates in the order of $2-5 \mathrm{~mm} \mathrm{year}^{-1}$ for the youngest uplift episode. In a similar way, from a corrected $S_{R}$ age estimate of 350-400 ka and $G_{n}$ twork values of $410-420 \mathrm{~m}$ in the central sector, we derive a minimum uplift rate of $1.05-1.2 \mathrm{~mm} \mathrm{year}^{-1}$ for the penultimate uplift phase.

Fig. 13. Comparison of the main temporal discontinuities identified in the Quaternary evolution of the Corinth rift from various on- and offshore observation sources. Grey areas account for the age uncertainty of some discontinuities. Groups of data sources attesting the same discontinuity are framed by rounded rectangles. Vertical arrows locate phases of acceleration (of uplift or extension). U: uplift (Backert et al., 2010; Briole et al, 2000).

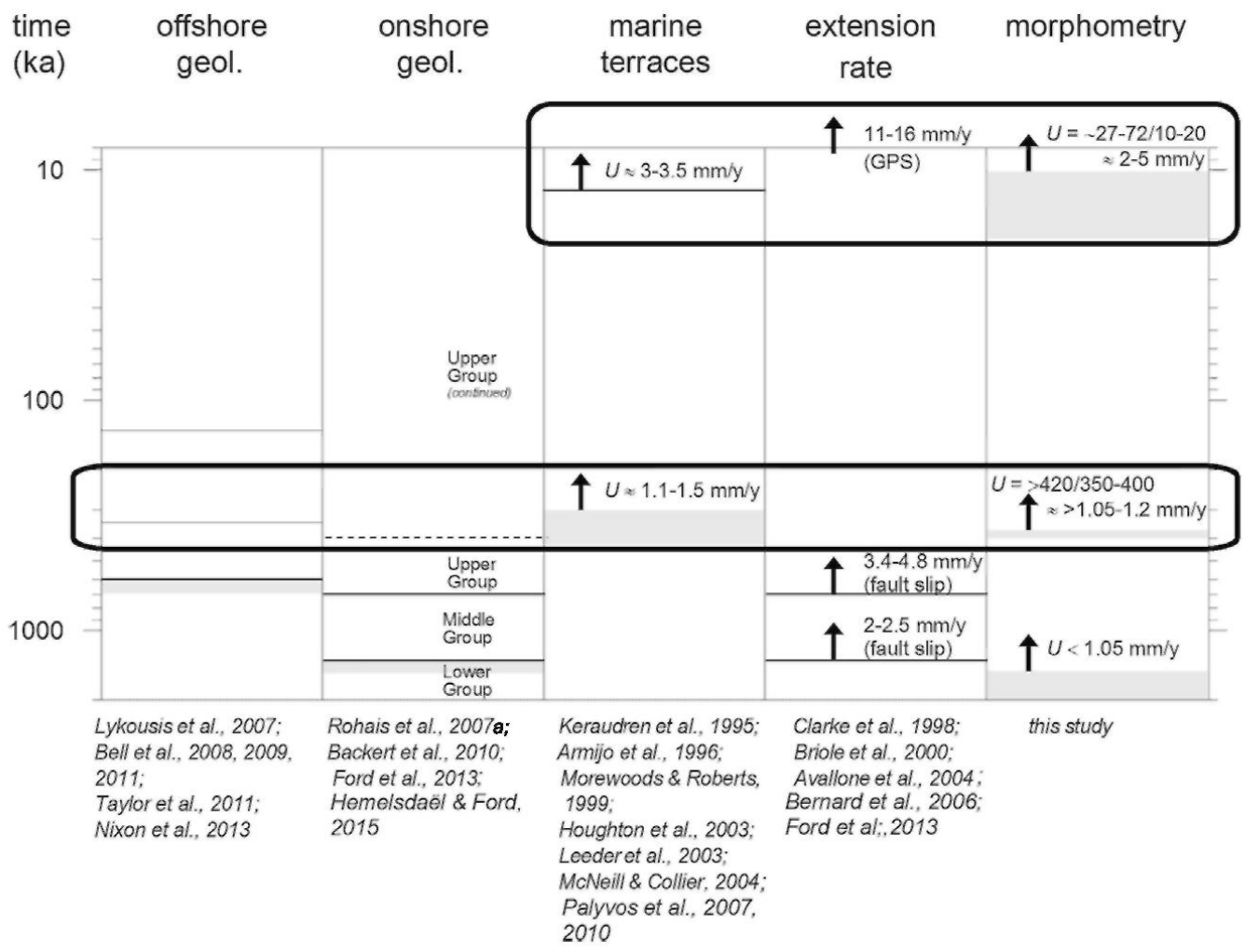


Interestingly, the identified E-W variations in uplift rate and timing may also be related to the activity of individual faults. Relying on the widely accepted scheme of the northern migration of fault activity with time (e.g., Leeder et al., 2008; Ford et al., 2013), these relationships show that (1) either the West Heliki and Lakka faults or the Pirgaki fault was especially active during the Early Pleistocene phase of uplift, (2) the Valimi fault seems to be the only one for which a Middle Pleistocene phase of activity is clearly recorded in the upstream $R$ profiles of the Krathis and the Krios (although the Vouraikos gorge might similarly attest significant activity of the Mamousia fault in the same period), and (3) intense Holocene activity of the East Heliki and/or Akrata faults caused the fastest recent uplift and river incision in this sector, while significant incision also occurred in the footwall of the onshore Xylokastro fault. This yields an overall picture where progressive concentration of maximum uplift in the central sector superposed since the early Pleistocene upon the northern migration of the active southern margin of the rift.

\subsection{Integrating morphometric and geological data}

Having shown the remarkable internal consistency of the morphometric results, we now discuss their integration with other on- and offshore data sets based on the synthesis of Fig. 13.

\subsubsection{Episodic character of shoulder uplift}

A main result of the morphometric analysis is that the fluvial landscape of the northern Péloponnèse preserves records of three distinct uplift phases featuring stepwise increasing uplift rates. This sequencing of the rift evolution is similar to that recognized in the syn-rift fill exposed in this area (Rohais et al., 2007b), with episodic strain migration and increase in extension rates (Ford et al., 2013). It is also to some extent in line with the number of main discontinuities revealed by the seismic imaging of the basin fill (Bell et al., 2009; Taylor et al., 2011; Nixon et al., 2013), although age and nature of these discontinuities are still debated and do not fully correlate with those provided here. Importantly, the intermediate episode of uplift imprinted in the fluvial morphology has been formally identified only in the catchments of the central part of the rift shoulder. However, the presence of deep gorges and huge knickzones in the Vouraikos and Ladopotamos valleys suggests that they too responded to this uplift phase, which thus affected a zone extending from Derveni in the east to Diakopto in the west (Fig. 1). This corresponds to the part of the Peloponnese coastline that faces the central part of the rift where Bell et al. (2011) identified a maximum in summed fault displacement since $0.4 \mathrm{Ma}$.

\subsubsection{Timing of the uplift phases}

With a latest phase of uplift increase (-2-5 mm year ${ }^{-1}$ ) identified around 10-20 ka, the morphometric evidence fully confirms the Holocene acceleration of uplift deduced from the ${ }^{14} \mathrm{C}$ ages obtained by Soter (1998) and Pirazzoli et al. (2004) for raised shorelines, which indicate recent uplift rates in the range 2.5-3.5 mm year in $^{-1}$ the central sector of the coast and $-1.35 \mathrm{~mm}_{\text {year }}{ }^{-1}$ for the Perachora Peninsula, in both cases significantly higher than the corresponding Middle and Late Pleistocene rates of, respectively, 1.1-1.5 and $<0.7 \mathrm{~mm} \mathrm{year}^{-1}$ (De Martini et al., 2004; McNeill and Collier, 2004; Morewood and Roberts, 1999). This accelerated Holocene uplift is also consistent with the observed discrepancy between hiceeding $10 \mathrm{~mm}_{\text {year }}{ }^{-1}$ in the central rift according to geodetic measurements (Clarke et al., 1998; Avallone et al., 2004), and much lower long-term rates, smaller than $5 \mathrm{~mm}$ year ${ }^{-1}$ during the last $0.7 \mathrm{Ma}$ in the same area (Ford et al., 2013). Furthermore, the intriguing westward increase in GPS-derived extension rates (e.g., Bell et al., 2011) parallels the $S_{\mathrm{R}}$-inferred westward decrease in age of the recent uplift acceleration. Therefore, we suggest that, rather than betraying a long-term feature (Clarke et al., 1998), the E-W gradient in GPS rate might be a short-term feature resulting from high impulse rates located at the tip of an E-W propagating extension/uplift signal and rapidly decaying to lower rates once the signal is passed. This reconciles the GPS data with the main body of evidence by decoupling it from the longterm data. By contrast, the 10-20 ka event seems not to be observed yet in the offshore record.

As for the penultimate uplift episode, its corrected $S_{R}$-inferred age estimate of 350-400 ka, consistent with the $\mathrm{GR}_{\text {network}}$-derived estimate of 320-415 ka, corresponds to a time inferred from several other data sets. Onshore, the oldest ages obtained for marine terraces on the foot-wall of the Aegion, Heliki, and Xylokastro faults suggest that the beginning of the corresponding uplift phase date back to 350-450 ka (Armijo et al., 1996; McNeill and Collier, 2004; Ford et al., 2013, and references therein), and a radiometric U-series dating by Vita-Finzi (1993) of perched delta deposits of the Upper Group of Rohais et al. (2007b) provide an age of $386 \mathrm{ka}$. The morphometric age estimates may also be paralleled with the basin-scale prominent unconformity observed by Taylor et al. (2011) in the gulfs seismic profiles and tentatively dated to $335 \mathrm{ka}$. However, this date relies on the assumption of a discontinuity pattern based on the beat of the sea level highstand-lowstand alternation and has apparently little to do with uplift events, except maybe that the $335 \mathrm{ka}$ discontinuity might appear sharper than others just because of co-occurrence of the climatic and tectonic triggers at this time. Furthermore, the morphometric results bring a new important piece in the jigsaw by delimiting the area affected by this major event between the Vouraikos and Krios valleys. A possible cause to higher uplift rates in this area around 0.35- 
0.4 Ma has been identified by Hemelsdaël and Ford (2015), who show that the Middle Pleistocene linkage history between the eastward propagating East Heliki fault and the Derveni fault, where the Krathis river flows into the Gulf of Corinth, included a phase of relay zone uplift and valley incision in this same time span.

Strikingly, the morphometric data do not evidence any discontinuity in the onshore evolution of the southern rift shoulder around $0.7 \mathrm{Ma}$, which however appears in the onshore syn-rift stratigraphy as the starting time of Upper Group deposition (Rohais et al., 2007b) and might also be correlated with the 0.7-0.6 Ma age assigned to the first-order discontinuity in the seismic profiles (Taylor et al., 2011 ; Nixon et al., 2013). A possible reason for the absence of morphometric record of this $0.7 \mathrm{Ma}$ discontinuity might be that the time span between $0.7 \mathrm{Ma}$ and the 0.35-0.4 Ma event was needed for the uplifting footwall of the Heliki and Xylokastro faults to emerge definitively, raising terraces and causing changes in onshore $S_{R}$ and a transient signal in offshore sedimentation (the 0.335 Ma unconformity of Taylor et al., 2011) only from the latter time onwards.

Finally, the oldest morphometrically identified uplift phase, older than $1 \mathrm{Ma}$ in the western part of the rift shoulder, probably correlates with the uplift episode that triggered the major erosional event separating around 1.5 Ma the Lower and Middle Groups of the syn-rift fill (Ford et al., 2013). In the east, local upstream $S_{R}$ values assign the uplift of the Péloponnèse coast facing the gulf of Lechaion to the Pliocene, after which no morphometrically discernible change is recorded in the vertical behaviour of the area until the Holocene. The absence of morphometric hiatus in the fluvial landscape of this region from the Pliocene to the Holocene might result from uplift rates varying little with time in the $0.0-0.3 \mathrm{~mm}_{\text {year }}^{-1}$ range, thus unable to induce measurable changes in the erosional landscape evolution.

\subsubsection{Spatial variability of uplift}

All basin-scale metrics attest similar E-W variations pointing to highest uplift rates in the central part of the rift shoulder (Fig. 5) between Heliki and Derveni (from the Selinous to the Krios catchments) during the older phases of uplift (Middle and Late Pleistocene). This is fully consistent with the offshore isopach maps of Bell et al. (2009) and Taylor et al. (2011), which show major depocentres located in front of Akrata during these times, and with the long-term data compiled by Bell et al. (2011), namely whole-crust extension and post-0.4 Ma summed fault displacements, which also culminate in the central sector. Onshore, the uplift rate information delivered by marine terrace studies requires more careful examination. Following Armijo et al. (1996), many authors consider that, beyond a background regional rate of- $0.2 \mathrm{~mm}$ year ${ }^{-1}$, the E-W gradient in terrace uplift, observed in particular between Xylokastro and Corinth, is correlated with their location more or less remote from the fault trace, indicating backtilting of the Xylokastro fault footwall. However, based on observations of uplifted terraces in other places, Leeder et al. (2003) conclude that uniform uplift from Perachora through the Corinth Isthmus to the terraces south of Corinth reveals a regional trend rather than footwall backtilting of active E-W faults. Independent of proximity to fault, the morphometric evidence of a regional E-W gradient in uplift rate clearly supports the conclusion of Leeder et al. (2003) and firmly establishes the interpretation of maximum Middle and Late Pleistocene uplift in the central part of the southern rift shoulder.

Downstream $k_{s n}$ values are another indicator of uplift rate that points to maximum uplift in the central part of the Peloponnese coast also during the latest, Holocene, episode of uplift. However, the area of maximum uplift is now displaced slightly eastward (Figs. 10 and 11), including the Trikalitikos valley, which joins the gulf at Xylokastro. This is again consistent with offshore observations that describe an eastward shift of the most recent depocentre, now located in front of Xylokastro (Bell et al., 2009; Taylor et al., 2011). Finally, our morphometric results also converge with all existing data sets in showing that uplift was minimum in the far eastern part of the Péloponnèse coast during the whole Quaternary.

\section{CONCLUSIONS}

Numerous studies have dealt with seismic analysis of the sedimentation in the Gulf of Corinth, with the tectonosedimentary history revealed by the uplifted syn-rift basin fill exposed in the northern Péloponnèse, and with raised marine terraces preserved along the coast. However, little, mostly superficial research was devoted to the analysis of the fluvial landscape produced by the response of the drainage system to the successive tectonic signals imposed to the region. Based on the use of a large set of classical and new basin and long profile metrics complemented by the new $R / S_{R}$ integrative approach of the regional drainage network, we have carried out a detailed morphometric analysis of the northern Péloponnèse landscape. The combined interpretation of independent metrics showing a remarkable internal consistency has provided a lot of quantitative information on the time, location, and intensity of the Plio-Quaternary tectonic episodes of uplift that caused regional relative base level lowering large enough to trigger waves of regressive erosion with measurable morphological effects. Our main result is the uncovering of three distinct episodes of uplift, of which the intermediate, dated around 
0.35-0.4 Ma, is only recorded in the topography of the central part of the rift shoulder, and the youngest seems to have propagated from east to west over the last 10-20 ka, possibly explaining the observed E-W variation in GPS-derived extension rates. While net uplift remained minimum in the eastern part of the study area during the whole Quaternary, it shows a clear maximum in the central part of the rift shoulder since 0.4 Ma and an eastward shift of this maximum in recent times. Maximum uplift rates calculated from the morphometric data are of $>$ 1.05 and 2-5 $\mathrm{mm} \mathrm{year}^{-1}$ for the mid-Middle Pleistocene and Holocene uplift episodes, respectively.

Overall, the morphometric evidence reveals an onshore uplift history that parallels, in every essential point, the history of rift activity deduced from offshore studies and that is also consistent with other onshore data sets. In the long term, it underlines a stable pattern of maximum activity in the central part of the rift and of its southern shoulder, confirming previous conclusions of absence of rift propagation during the Quaternary (Leeder et al., 2008). This is not necessarily contradictory with the eastward rift propagation more recently suggested by Leeder et al. (2012) for an earlier, Late Pliocene stage of rift evolution, which cannot be inferred using our morphometric data. In the short term, it sheds new light on the possible E-W migration of the recently begun uplift phase, suggesting that fault activity and seismic hazard might concentrate in the immediate future in the Heliki-Aegion area at the western tip of this uplift wave. This is only one of the research perspectives opened by the morphometric approach to the Corinth rift evolution.

\section{ACKNOWLEDGMENTS}

We thank P. Briole, who provided us with the ISTAR DEM of the study area. A. Beckers participated to this research in the frame of a FR1A grant of the Fonds de la Recherche Scientifique of the Wallonia-Brussels Federation. M. Ford and an anonymous reviewer are warmly thanked for their fair and constructive remarks. The paper was also edited by T. Oguchi.

\section{REFERENCES}

Armijo, R, Meyer, B, King, G., Rigo, A, Papanastassiou, D, 1996. Quaternary evolution of the Corinth Rift and its implications for the Late Cenozoic evolution of the Aegean. Geophys.J.Int. 126,11-53.

Armijo, R, Meyer, B., Hubert, A., Barka, A., 1999. Westward propagation of the north Anatolian into the northern Aegean: timing and kinematics. Geology 27, 267-270.

Avallone, A., Briole, P., Agatza-Balodimou, A.M., Billiris, H., Charade, 0., Mitsakaki, C, Nercessian, A., Papazissi, K, Paradissis, D, Veis, G., 2004. Analysis of eleven years of deformation measured by GPS in the Corinth Rift Laboratory area. Compt. Rendus Geosci. 336, 301311 .

Backert, N, Ford, M, Malartre, F, 2010. Architecture and sedimentology of the Kerinitis Gilbert-type fan delta, Corinth Rift, Greece. Sedimentology 57, 543-586.

Beckers, A, Bovy, B, Hallot, E., Demoulin, A, 2014. Controls on knickpoint migration in a drainage network of the moderately uplifted Ardennes Plateau, Western Europe. Earth Surf. Proc. Land, http://dx.doi.org/10.1002/esp.3638.

Beckers, A, Hubert-Ferrari, A, Beck, C, Bodeux, S, Tripsanas, E, Sakellariou, D., De Batist, M., 2015. Active faulting at the western tip of the Gulf of Corinth, Greece, from high-resolution seismic data. Mar. Geol. 360, 55-69. http://dx.doi.Org/10.1016/j.margeo. 2014.12.003.

Bell, R., McNeill, L, Bull, J., Henstock, T., 2008. Evolution of the offshore western Gulf of Corinth. Geol. Soc. Am. Bull. 120,156-178.

Bell, R, McNeill, L, Bull, J., Henstock, T., Collier, R, Leeder, M., 2009. Fault architecture, basin structure and evolution of the Gulf of Corinth Rift, central Greece. Basin Res. 21,824-855

Bell, R, McNeill, L, Henstock, T, Bull, J., 2011. Comparing extension on multiple time and depth scales in the Corinth Rift, Central Greece. Geophys. J. Int 186,463-470.

Bernard, P., Lyon-Caen, H., Briole, P., Deschamps, A., Boudin, F., Makropoulos, K., Papadimitriou, P., Lemeille, F., Patau, G., Billiris, H., Paradissis, D., Papazissi, K., Castarède, H., Charade, O., Nercessian, A., Avallone, A., Pacchiani, F., Zahradnik, J., Sacks, S, Linde, A, 2006. Seismicity, deformation and seismic hazard in the western rift of Corinth: new insights from the Corinth Rift Laboratory (CRL) Tectonophysics 426, 7-30.

Bishop, M., Shroder, J, Bonk, R, Olsenholler, J, 2002. Geomorphic change in high mountains: a western Himalayan perspective. Glob. Planet. Chang. 32,311-329.

Bishop, P., Hoey, T., Jansen, J., Artza, I., 2005. knickpoint recession rate and catchment area: the case of uplifted rivers in Eastern Scotland. Earth Surf. Proc. Land. 30, 767-778.

Briole, P., Rigo, A., Lyon-Caen, H., Ruegg, J.C., Papazissi, K., Mitsakaki, C, Balodimou, A., Veis, G., Hatzfeld, D., Deschamps, A., 2000. Active deformation of the Corinth rift, Greece: results from repeated Global Positioning System surveys between 1990 and 1995 . J. Geophys. Res. B105, 25,605-25,625.

Brocklehurst, S, Whipple, K, 2004. Hypsometry of glaciated landscapes. Earth Surf. Proc. Land. 29, 907-926.

Champagnac, J., Molnar, P, Anderson, R, Sue, C, Delacou, B, 2007. Quaternary erosion-induced isostatic rebound in the western Alps. Geology 35,195-198.

Chen, Y., Sung, Q, Cheng, K, 2003. Along-strike variations of morphotectonic features in the Western Foothills of Taiwan: tectonic 
implications based on stream-gradient and hypsometric analysis. Geomorphology 56,109-137.

Clarke, P., Davies, R, England, P., Parsons, B., Billiris, H., Paradissis, D., Veis, G., Cross, P., Denys, P., Ashkenazi, V., Bingley, R., Kahle, H., Muller, M., Briole, P., 1998. Crustal strain in central Greece from repeated GPS measurements in the interval 1989-1997. Geophys. J. Int $135,195-214$

Collier, R, Leeder, M, Rowe, P., Atkinson, T, 1992. Rates of tectonic uplift in the Corinth and Megara basins, central Greece. Tectonics $11,1159-1167$

Collier, R, Leeder, M., Trout, M, Ferentinos, G., Lyberis, E., Papatheodorou, G., 2000. High sediment yields and cool, wet winters : test of last glacial paleodimates in the northern Mediterranean. Geology 28, 999-1002.

Croissant T, 2012. Application à des paysages synthétiques d'une nouvelle mesure morphométrique permettant de determiner l'âge d'un soulèvement tectonique. Unpublished Mémoire de Recherche, Univ.J. Fourier, Grenoble, 24 pp.

De Martini, P, Pantosti, D, Palyvos, N, Lemeille, F., McNeill, L, Collier, R, 2004. Slip rates of the Aigion and Eliki Faults from uplifted marine terraces, Corinth Gulf, Greece. Compt Rendus Geosci. 336, 325-334.

Demoulin, A, 2011. Basin and river profile morphometry: a new index with a high potential for relative dating of tectonic uplift Geomorphology 126, 97-107.

Demoulin, A., 2012. Morphometric dating of the fluvial landscape response to a tectonic perturbation. Geophys. Res. Lett. 39 , L15402. http://dx.doi.org/10.1029/2012GL052201.

Demoulin, A., Altin, T.B., Beckers, A, 2013. Morphometric age estimate of the last phase of accelerated uplift in the Kazdag area (Biga Peninsula, NW Turkey). Tectonophysics 608,1380-1393.

Dia, A, Cohen, A., O'Nions, R, Jackson, J, 1997. Rates of uplift investigated through ${ }^{230 T h}$ dating in the Gulf of Corinth (Greece). Chem Geol. $138,171-184$

Doutsos, T., Piper, D, 1990. Listric faulting, sedimentation, and morphological evolution of the Quaternary eastern Corinth rift, Greece: first stages of continental rifting. Geol. Soc. Am Bull. 102, 812-829.

Doutsos, T., Koukouvelas, K., Xypolias, P., 2006. A new orogenic model for the External Hellenides. In: Robertson, A., Mountrakis, D. (Eds.), Tectonic Development of the Eastern Mediterranean Region. Geol. Soc, London, Spec. Publ. 260, pp. 507-520.

Flint, J., 1974. Stream gradient as a function of order, magnitude, and discharge. Water Resour. Res. 10, 969-973. Ford, M, Rohais, S., Williams, E., Bourlange, S., Jousselin, D., Backert, N., Malartre, F., 2013. Tectono-sedimentary evolution of the western Corinth rift (Central Greece). Basin Res. 25, 3-25.

Friedrich, A., Wernicke, B, Niemi, N., Bennett, R, Davis, J., 2003. Comparison of geodetic and geologic data from the Wasatch region, Utah, and implications for the spectral character of Earth deformation at periods of 10 to 10 million years. J. Geophys. Res. $108,2199$. http://dx.doi.org/10.1029/2001JB000682.

Gao, M., Zeilinger, G, Xu, X, Wang, Q, Hao, M., 2013. DEM and GIS analysis of geomorphic indices for evaluating recent uplift of the northeastern margin of the Tibetan Plateau, China. Geomorphology 190,61-72. Hack, J-, 1973. Stream profile analysis and stream-gradient index. J. Res. US Geol. Surv. 1, 421-429. Hemelsdaël, R, Ford, M., 2015. Relay zone evolution: a history of repeated fault propagation and linkage, central Corinth rift, Greece. Basin Res. 1-23 http://dx.doi.org/10.1111/bre.12101.

Houghton, S., Roberts, G., Papanikolaou, I., McArthur, J., Gilmour, M., 2003. New ${ }^{234} \mathrm{U}_{-}^{230}$ Th coral dates from the western Gulf of Corinth implications for extensional tectonics. Geophys. Res. Lett. 30. http://dx.doi.org/10.1029/2003GL018112.

Keraudren, B., Sorel, D., 1987. The terraces of Corinth (Greece). A detailed record of eustatic sea-level variations during the last 500,000 years. Mar. Geol. 77, 99-107.

Keraudren, B., Falguères, C, Bahain, J.J, Sorel, D, Yokoyama, Y, 1995. Nouvelles datations radiométriques des terrasses marines de Corinthie (Péloponnèse septentrional, Grèce). CR Acad. Sci. Paris 320,483-489.

Korup, O, Schmidt, J, McSaveney, M, 2005. Regional relief characteristics and denudation pattern of the western Southern Alps, New Zealand. Geomorphology 71, $102-123$

Lague, D, 2014. The stream power river incision model: evidence, theory and beyond. Earth Surf. Proc. Land. 39,38-61. Leeder, M, Harris, T, Kirkby, M, 1998. Sediment supply and climate change: implications for basin stratigraphy. Basin Res. 10, 7-18.

Leeder, M, McNeill, L, Collier, R, Portman, C, Rowe, P, Andrews, J, Gawthorpe, R, 2003. Corinth rift margin uplift: new evidence from Late Quaternary marine shorelines. Geophys. Res. Lett 30,1611. http://dxdoi.org/10.1029/2003GL017382.

Leeder, M, Mack, G, Brasier, A, Parrish, R, Mcintosh, W, Andrews, J, Duermeijer, C, 2008. Late-Pliocene timing of Corinth (Greece) riftmargin fault migration. Earth Planet Sci. Lett. 274,132-141.

Leeder, M, Mark, D, Gawthorpe, R, Kranis, H, Loveless, S, Pedentchouk, N, Skourtsos, E.,Turner, J, Andrews, J, Stamatakis, M, 2012. A "Great Deepening": chronology of rift climax, Corinth rift, Greece. Geology 40, 999-1002.

Loget, N., Van Den Driessche, J, 2009. Wave train model for knickpoint migration. Geomorphology 106,376-382.

Lykousis, V, Sakellariou, D, Moretti, I, Kaberi, H, 2007. Late Quaternary basin evolution of the Gulf of Corinth: sequence stratigraphy, sedimentation, fault-slip and subsidence rates. Tectonophysics 440,29-51.

Maroukian, H, Gaki-Papanastassiou, K, Karymbalis, E, Vouvalidis, K, Pavlopoulos, K., Papanastassiou, D, Albanakis, K, 2008. Morphotectonic control on drainage network evolution in the Perachora Peninsula, Greece. Geomorphology 102, 81-92.

McNeill, L, Collier, R, 2004. Uplift and slip rates of the eastern Eliki fault segment, Gulf of Corinth, Greece, inferred from Holocene and Pleistocene terraces. J. Geol. Soc. 161, 81-92.

McNeill, L, Collier, R, De Martini, P, Pantosti, D, D'Addezio, G, 2005. Recent history of the Eastern Eliki Fault, Gulf of Corinth: 
Published in : Geomorphology (2015), vol. 246, pp. 188-204

Status : Postprint (Author's version)

geomorphology, palaeoseismology and impact on palaeoenvironments. Geophys. J. Int 161,154-166.

Morewood, N, Roberts, G, 1999. Lateral propagation of the surface trace of the South Alkyonides normal fault segment, central Greece: its impact on models of fault growth and displacement length relationships. J. Struct Geol. 21, 635-652.

Mudd, S, Attal, M., Milodowski, D, Grieve, S, Valters, D, 2014. A statistical framework to quantify spatial variation in channel gradients using the integral method of channel profile analysis. J. Geophys. Res. Earth Surf. 119, 138-152. http://dx.doi.org/10. 1002/2013JF002981.

Nixon, C, McNeill, L, Henstock, T., Bull, J, Bell, R., Christodoulou, D., Papatheodorou, G, Taylor, B., Ferentinos, G., Sakellariou, D., Lykousis, V., Sachpazi, M., Ford, M., Goodliffe, A, Leeder, M., Gawthorpe, R, Collier, R, Clements, B, 2013. Basin evolution, organization of faulting and the distribution of displacement within the Gulf of Corinth rift Am Geophys. Union Fall Meeting 2013,2013AGUFM.T21B2556N

Nyst, M., Thatcher, W., 2004. New constraints on the active tectonic deformation of the Aegean. J. Geophys. Res. 109 , B11406. http://dx.doi.org/10.1029/2003JB002830.

Ori, G., 1989. Geological history of the extensional basin of the Gulf of Corinth (Miocene-Pleistocene), Greece. Geology 17, $918-921$.

Palyvos, N., Sorel, D, Lemeille, F, Mancini, M., Pantosti, D., Julia, R, Triantaphyllou, M, De Martini, P., 2007. Review and new data on uplift rates at the W termination of the Corinth Rift and the NE Rion graben area (Achaia, NW Peloponnesos). Bull. Soc. Geol. Greece 40,412-424.

Palyvos, N., Mancini, M., Sorel, D., Lemeille, F., Pantosti, D., Julia, R, Triantaphyllou, M, De Martini, P., 2010. Geomorphological, stratigraphie, and geochronological evidence of fast Pleistocene coastal uplift in the westernmost part of the Corinth Gulf Rift (Greece). Geol. J. 45, 78-104.

Perez-Pena, J., Azanôn, J., Booth-Rea, G., Azor, A., Delgado, J., 2009a. Differentiating geology and tectonics using a spatial autocorrelation technique for the hypsometric integral. J. Geophys. Res. 114F, F02018. http://dx.doi.org/10.1029/2008JF001092.

Perez-Pena, J, Azanôn, J, Azor, A, Delgado, J., Gonzâlez-Lodeiro, F., 2009b. Spatial analysis of stream power using GIS: SLk anomaly maps. Earth Surf. Proc. Land. 34,16-25.

Perissoratis, C, Piper, D, Lykousis, V, 2000. Alternating marine and lacustrine sedimentation during late Quaternary in the Gulf of Corinth rift basin, central Greece. Mar. Geol. 167,391-411.

Perron, J.T., Royden, L, 2013. An integral approach to bedrock river profile analysis. Earth Surf. Proc. Land. 38, 570-576.

Piper, D., Perissoratis, C, 1991. Late Quaternary sedimentation on the continental margin of Northern Greece. Am. Assoc Petrol. Geol. Bull. 75,46-61.

Pirazzoli, P., Stiros, S, Fontugne, M, Arnold, M, 2004. Holocene and Quaternary uplift in the central part of the southern coast of the Corinth Gulf (Greece). Mar. Geol. 212,35-44

Roberts, G, White, R, 2010. Estimating uplift rate histories from river profiles using African examples. J. Geophys. Res. 115 , B02406. http://dx.doi.org/10.1029/2009JB006692.

Rohais, S., Eschard, R, Ford, M, Guillocheau, F., Moretti, I., 2007a. Stratigraphie architecture of the Plio-Pleistocene infill of the Corinth Rift: implications for its structural evolution. Tectonophysics 440, 5-28.

Rohais, S, Joannin, S., Colin, J.P., Suc.J.P., Guillocheau, F., 2007b. Age and environmental evolution of the syn-rift fill of the southern coast of the Gulf of Corinth (Akrata-Derveni region, Greece). Bull. Soc. Geol. Fr. 178, 231-243.

Sachpazi, M., Galvé, A, Laigle, M, Hirn, A, Sokos, E., Serpetsidaki, A, Marthelot, H.J.M., Pi Alperin, J., Zelt, B., Taylor, B., 2007. Moho topography under central Greece and its compensation by Pn time-terms for the accurate location of hypocenters: the example of the Gulf of Corinth 1995 Aigion earthquake. Tectonophysics 440, 53-65.

Seeber, L, Gornitz, V, 1983. River profiles along the Himalayan arc as indicators of active tectonics. Tectonophysics 92, 335-367.

Sklar, L, Dietrich, W., 2001. Sediment and rock strength controls on river incision into bedrock Geology 29,1087-1090.

Skourlis, K, Doutsos, T, 2003. The Pinos fold-and-thrust belt (Greece) : inversion kinematics of a passive continental margin. Int J. Earth Sci. $92,891-903$

Small, E., Anderson, R, 1998. Pleistocene relief production in Laramide mountain ranges, western United States. Geology 26,123-126.

Snyder, N., Whipple, K., Tucker, G., Merritts, D., 2000. Landscape response to tectonic forcing: DEM analysis of stream profiles in the Mendocino triple junction region, northern California. Geol. Soc. Am. Bull. 112,1250-1263.

Soter, S., 1998. Holocene uplift and subsidence of the Helike Delta, Gulf of Corinth, Greece. In: Stewart, I., Vita-Finzi, C. (Eds.), Coastal Tectonics. Geol. Soc, London, Spec. Publ. 146, pp. 41-56.

Stefatos, A., Papatheodorou, G., Ferentinos, G., Leeder, M., Collier, R, 2002. Seismic reflection imaging of active offshore faults in the Gulf of Corinth: their seismotectonic significance. Basin Res. 14,487-502.

Sternai, P., Herman, F., Fox, M., Castelltort, S., 2011. Hypsometric analysis to identify spatially variable glacial erosion. J. Geophys. Res. 116F, F03001. http://dx.doi.org/10.1029/201 OJFOO1 823

Strahler, A, 1952. Hypsometric (area-altitude) analysis of erosional topography. Bull. Geol. Soc. Am. 63,1117-1142.

Taylor, B., Weiss, J., Goodliffe, A., Sachpazi, M., Laigle, M., Hirn, A., 2011. The structures, stratigraphy and evolution of the Gulf of Corinth rift, Greece. Geophys. J. Int. 185, 1189-1219.

Vassilakis, E., Skourtsos, E., Kranis, H., 2007. Estimation of tectonic uplift rate using quantified morphometric indices. Proc. 8th PanHellenic Geogr. Conf. National and Kapodistrian Univ., Athens, pp. 17-26.

Vita-Finzi, C, 1993. Evaluating late Quaternary uplift in Greece and Cyprus. In: Prichard, H., Alabaster, T, Harris, N, Neary, C. (Eds.), 
Published in : Geomorphology (2015), vol. 246, pp. 188-204

Status : Postprint (Author's version)

Magmatic Processes and Plate Tectonics. Geol. Soc, London, Spec. Publ. 76, pp. 417-424.

Whipple, K., 2001. Fluvial landscape response time: how plausible is steady-state denudation? Am. J. Sci. 301,313-325.

Whipple, K., Tucker, G., 2002. Implications of sediment-flux-dependent river incision models for landscape evolution. J. Geophys. Res. 107B, 2039. http://dx.doi.org/10.1029/2 000JB000 044.

Whittaker, A, Boulton, S, 2012. Tectonic and climatic controls on knickpoint retreat rates and landscape response times. J. Geophys. Res. 117, F02024. http://dx.doi.org/10.1029/2011JF002157.

Whittaker, A, Cowie, P, Attal, M., Tucker, G., Roberts, G., 2007. Contrasting transient and steady-state rivers crossing active normal faults: new field observations from the central Apennines, Italy. Basin Res. 19, 529-556.

Willgoose, G., Hancock G, 1998. Revisiting the hypsometric curve as an indicator of form and process in transport-limited catchment Earth Surf. Proc. Land. 23, 611-623.

Wobus, C, Whipple, K., Kirby, E., Snyder, N., Johnson, J., Spyropolou, K., Crosby, B., Sheehan, D, 2006. Tectonics from topography: procedures, promise, and pitfalls. In: Willett, S, Hovius, N., Brandon, M., Fisher, D. (Eds.), Tectonics, Climate, and Landscape Evolution. Geol. Soc. Am. Spec Pap. 398, pp. 55-74. http://dx.doi.org/10.1130/2006.2398(04).

Ye, F., Barriot, J.P., Carretier, S, 2013. Initiation and recession of the fluvial knickpoints of the Island of Tahiti (French Polynesia). Geomorphology 186,162-173. 